\title{
LA FÁBULA BURLESCA DE CRISTO Y LA MAGDALENA, DE MIGUEL DE BARRIOS
}

\section{La fábula mitológica burLesca}

Las fábulas "burlescas" (llamadas también “jocosas", o a veces “joco-serias") son un género poético que hizo furor durante el Barroco hispánico'. Su iniciador, Góngora, desde época muy temprana se había divertido en tomar a chunga tres tipos de romances que hacia 1580 estaban de moda: los carolingios ("Diez años vivió Belerma...", "Desde Sansueña a París..."), los pastoriles ("En la pedregosa orilla...", “Ensíllenme el asno rucio...") y los moriscos ("Triste pisa y afligido..."). Estas parodias son de entre 1582 y 1586. De ahí saltó Góngora a la burla de los romances mitológicos: la historia de Hero y Leandro ("Arrojóse el mancebito / al charco de los atunes...", 1589), la de Píramo y Tisbe ("De Tisbe y Píramo quiero...", 1604), de nuevo la de Hero y Leandro ("Aunque entiendo poco griego...", 1610) y, finalmente, de nuevo la de Píramo y Tisbe

${ }^{1}$ El benemérito José MARÍA DE Cossío estudia o menciona muchas de ellas en sus Fábulas mitológicas en España. - He aquí, de una vez, las abreviaturas que emplearé en las páginas que siguen:

Cossío: el libro que acabo de citar (Madrid, 1952);

"Fortuna varia": A. Alatorre, "Fortuna varia de un chiste gongorino", NRFH, 15 (1961), 483-504;

Magdalena: la Fábula de Christo y la Magdalena, cuya edición se verá adelante;

Oelman: Timothy Oelman, "Tres poetas marranos" [João Pinto Delgado, Antonio Enríquez Gómez y Miguel de Barrios], NRFH, 30 (1981), 184-206;

Scholberg: Kenneth R. Scholberg, La poesia religiosa de Miguel de Barrios, Ohio State University, s. a. (ca. 1962);

Verdad, (La): Contra la Verdad no hay fuerza, comedia de Miguel de Barrios, apud SchOLBERG, pp. 249-341. 
("La ciudad de Babilonia... ", 1614), obra de su madurez, culminación exquisita de todo lo anterior ${ }^{2}$.

Vino luego la avalancha de los continuadores e imitadores: primero varios poetas de la valenciana Academia de los Nocturnos (1591-1594), y luego Jacinto de Maluenda, Anastasio Pantaleón de Ribera, Jerónimo Cáncer, Salas Barbadillo, Quevedo ${ }^{3}$, Polo de Medina y muchos otros. Quienes más activos se mostraron en la empresa fueron Pantaleón de Ribera, con tres fábulas (Alfeo, Europa, Prosérpina), Jerónimo Cáncer, con tres también (Dafne, Atalanta, Ío), Polo de Medina, con cuatro (Vulcano, Siringa, Apolo y Dafne, Apolo y los poetas), Vicent García, rector de Vallfogona, también con cuatro, en catalán (Dánae, Vulcano, Siringa, Dafne), Castillo Solórzano, con siete (Vulcano, Siringa, Adonis, Acteón, Europa, Helena, Polifemo), y Miguel de Barrios, con ocho (Alfeo, Polifemo, Calisto, Vulcano, Adonis, Prometeo, Siringa, Tetis).

Así, pues, hacia 1675 era Barrios el campeón de los poetas españoles en cuanto a número de fábulas burlescas, el que más afición había mostrado a esa especie de juego de ingenio. Y como después de 1675 las fábulas burlescas entraron en decadencia, puede decirse que las suyas son el remate del género ${ }^{4}$. Remate

${ }^{2}$ Claro que la actitud paródica ante la antigüedad clásica venía de antes. Baste recordar a Diego Hurtado de Mendoza (por ejemplo los sonetos "Quien de tantos burdeles ha escapado..." y "iOh Venus, alcahueta y hechicera...!") y a Baltasar del Alcázar (por ejemplo su oda sáfica "Suelta la venda, sucio y asqueroso..." "). Sobre esto véase A. Alatorre, "Andanzas de Venus y Cupido...", Homenaje a Mercedes Díaz Roig, El Colegio de México, 1992, pp. 378-383). - Por otra parte, ya en "Ensillenme el asno rucio..." (1585) nos describe Góngora la patena del pastor Galayo, "donde de latón se ofrecen / la madre del virotero / y aquel dios que calza arneses [es decir, Venus y Marte, llamado luego “el dios garañón"], / tan en pelota y tan juntos...", etcétera.

${ }^{3}$ Cossío, p. 679, extrañamente dice que Quevedo no hizo fábulas burlescas. Se olvida de la Fábula de Orfeo ("Orfeo por su mujer...") y del Leandro y Hero en paños menores ("Señor don Leandro, / vaya enhoramala..."). Sobre los poetas de la Academia de los Nocturnos véase mi reseña del libro de Cossío, NRFH, 11 (1957), pp. 81-82.

${ }^{4}$ Siguió habiendo cultivadores esporádicos en el siglo xvIII, y algunos, como "Pedro Silvestre" y Joseph Moraleja, no lo hicieron mal. Notable es el caso de Francisco Nieto Molina (el poeta de la Perromaquia), que incluyó hasta nueve fábulas en su Fabulero (Madrid, 1764): Polifemo, Alfeo, Dafne, Siringa, Atalanta, Paris, Hero, Narciso, Europa. Pero lo que de golpe demuestran las fábulas de Nieto es que las venas del género estaban exhaustas: su Polifemo y su Hero y Leandro, por ejemplo, no son sino desvaídos refritos de Góngora. 
no brillante, hay que reconocerlo. Ninguna de las fábulas de Barrios es muy memorable.

Durante toda la época de las fábulas burlescas (digamos de 1589 a 1764) siguió habiendo fábulas "serias". De hecho, puede observarse cierto estira y afloja (o "tensión dialéctica") entre una y otra modalidad. En Ovidio, la fábula de Vulcano, donde Venus y Marte son cogidos in fraganti en la red metálica, es ya burlesca, y así seguirá siéndolo en su descendencia española. El Polifemo ovidiano tiene sus rasgos cómicos, acentuados moderadamente por Góngora y estrepitosamente por Castillo Solórzano. En cambio, la historia dolorosísima de Procne y Filomela no parecía admitir más que el estilo elevado, y sin embargo fue puesta en solfa, aunque tardíamente, por un poeta académico: “Mándame la señora Academía / cante la bobería / de los pájaros Progne y Filomela; / cómo, sin tener lengua esta mozuela, / cantó mejor y aun más que una cigarra..." ${ }_{5}$. De manera inversa, el Hero y Leandro de Trillo y Figueroa (1652), compuesto en un lenguaje que se pierde en las nubes de tan elevado, da la impresión de haberse escrito adrede para contrarrestar las irreverencias de Góngora. Quevedo, "hombre de Dios, hombre del Diablo", escribió dos romances de Hero y Leandro: uno conceptista a lo muy fino y el otro rematadamente chocarrero ${ }^{6}$. Sus quintillas De Dafne y Apolo son una delicadísima sarta de agude-

${ }^{5}$ Estos versos (de un tal Diego Blanco Carrillo) se leyeron en una academia de Salamanca en 1716 (Cossío, pp. 760-761). - En cambio, la nobilísima historia de Lucrecia fue caricaturizada en fecha muy temprana en un chocarrero romance que fue muy popular: "Dándose estava Lucrecia / de las astas con Tarquino [...]. Dezíale la matrona: / Passito, señor Tarquino, / que de mi honor la cerraja/ tiene muy fuerte el pestillo", etc. Este romance se imprimió por vez primera en la Quinta parte del Ramillete (1593) y fue muy reimpreso, copiado y parodiado. Sin duda influyó mucho en el desarrollo del "género burlesco". En el Índice de poesías atribuidas a Góngora (ed. Millé Giménez) figuran cuatro romances sobre Lucrecia: "Dándose estaba Lucrecia...", "Era vicario Tarquino...,", "Escribiendo está Lucrecia..." y "Luego que sacó Lucrecia...". Curiosamente, hubo quien convirtiera el romance "Dándose estaba Lucrecia..." en un romance "A la Magdalena": "Dándose está a penitençia/ en un áspero retiro..." (A. Rodríauez-Moñino y M. Brey, Catál. de los mss. poét. de la H.S.A., t. 1, p. 220).

${ }^{6}$ Respectivamente, "Esforzóse pobre luz..." y "Señor don Leandro...": véase A. Alajarre, "Los romances de Hero y Leandro", Libro jubilar de Alfonso Reyes, México, 1956, pp. 20-23 y 29-32. (Allí también, pp. 35-37, hay una somera reflexión acerca del Hero y Leandro de Trillo.) 
zas, alabadas por el gran catador Gracián, pero a Quevedo no le hubiera desagradado la sal gruesa con que trató esa historia un contemporáneo suyo, estudiante de Alcalá ${ }^{7}$. Finalmente, en muchas fábulas burlescas, comenzando con las de Góngora, alternan en mayor o menor medida lo "poético" y lo "prosaico"8.

Para mayor claridad, he aquí algunos ejemplos característicos de la vertiente chocarrera, elegidos auténticamente al azar, sin más programa que la exclusión de los poetas famosos: (1) Final del cuento de Diana y Acteón: “Cuernos le vino a poner / con ser tan casta mujer, / para mostrar, sin que asombre, / quál deve poner al hombre / la que lo deja de ser" (Miguel Beneito). - (2) Pasífae se introduce en la vaca hueca fabricada por el ingenioso Dédalo: "Y al tiempo que el toro busca / para su pajuela açufre, / para su cuchillo bayna, / para su punçón estuche, / llegó Minos su marido..." ( Jacinto Maluenda). - (3) Dánae y la lluvia de oro: "Estava acostada Dánae, / más de achaque que melindre, / quando Dios y enhorabuena, / ¡zas!, y un golpe le repite / en la almohada, y un doblón / ase, pensando que es chinche" (Melchior Zapata). - (4) El parto de Latona: "Parió in primis a Diana, / rapaza tan diligente, / que a ayudar a echar

7 Como bien demuestra M. Chevalier, "Gracián frente a Quevedo", NRFH, 36 (1988), 1069-1077, Quevedo no era santo de la devoción de Gracián. Así, pues, las varias y elogiosas citas de las quintillas De Dafne y Apolo que hay en la Agudeza y arte de ingenio (Obras completas, Madrid, 1944, pp. 71, 95, 97 y 126) son excepcionales. - La Fábula de Daphne y Apolo del estudiante de Alcalá está en $R H i, 40$ (1917), 122-124. He aquí, en Quevedo, el momento en que Apolo (el Sol) persigue a la ninfa: "El Sol corre por seguilla; / por huir corre la Estrella; / corre el llanto por no vella, / corre el aire por oílla / y el río por socorrella". Y he aquí ese momento en el estudiante de Alcalá: "Lanza en ristre la yva Apolo / picando la retaguardia. / Viendo que a lo italiano / la dava un bote de lanza, / volvió [Dafne] los ojos al cielo...". Por lo demás, también Quevedo tomó a risa la historia de Dafne (sonetos "Bermejazo platero de las cumbres..." y "Tras vos un alquimista va corriendo...").

${ }^{8}$ F. Lázaro Carreter, "Situación de la Fábula de Píramo y Tisbe", NRFH, 15 (1961), pp. 471-472, explica muy bien por qué el romance "De Tisbe y Píramo quiero..." quedó inconcluso: Góngora "alzó la pluma" al ver que lo que llevaba escrito era "una docena de coplas transparentes, ni cómicas ni graves". Él buscaba una fusión química de los dos lenguajes y comprendió que ese experimento era un fracaso (del cual se desquitó con creces en "La ciudad de Babilonia..."). Véase también la nota de D. L. Garrison, "The linguistic mixture of Góngora's Fábula de Píramo y Tisbe", $R N o, 20$ (1979-80), 108-113. - El romance "Triste pisa y afligido..." es un ensayo juvenil de fusión, no química, sino física: alternan en él, sistemáticamente, las cuartetas serias y las chistosas. 
las pares [la placenta] / patas arriba se vuelve; / con esta ayuda la enferma / parió a Apolo, tan valiente, / que con su ombligo colgando / dar muerte a Pitón emprende" (Gabriel Fernández de Rozas). - (5) Juno, Palas y Venus disputándose la manzana: "Empezáronse a arañar, / andaba el mojo la holla [?], / bofetada como el puño, / pescozada a toda costa. / ¡Ay, que me ha quebrado un ojo! / iQue me rompe la valona! / iAh puta! ¿Azotes a mí? / ¿Que me matan! ¿Que me ahogan!' (José Pérez de Montoro). - (6) Júpiter se muestra a Sémele con sus rayos y truenos: "Ardieron al instante / todos los elementos; / guisáron" se en el mundo / generalmente todos los pucheros" (Juan de Salcedo Ponce de León). - (7) Rapto de Prosérpina: "Coces daba Prosérpina y bocados, / mas muerde el aire y acocea el viento" ("Pedro Silvestre"). - (8) Alfeo contempla a Aretusa bañándose: ". . y viéndola allí desnuda, / entre sí pescarla traza: / que una muger vista en carnes / cerca está de ser pescada" (Joseph Moraleja).

Las agudezas chistosas no tardaron en introducirse en la poesía religiosa. Es divertido ver cómo una y otra vez, a lo largo de los años, se levantan voces que condenan esta práctica, y cómo también una y otra vez se componen, por ejemplo, vidas de santos en estilo joco-serio porque así lo pedían las convocatorias de las justas poéticas con que se festejaba alguna beatificación o canonización. Y es un hecho que estas composiciones, que “jugaban" a escandalizar a las almas devotas y que por lo general eran obra de frailes y clérigos, tuvieron siempre mucho éxito. Una vez se dio a glosar esta redondilla en loor de la Santa Cruz: "Cruz, remedio de mis males, / ancha sois, pues cupo en vos / el gran Pontífice, Dios, / con cinco mil cardenales', y no faltaron glosadores (nadie, que se sepa, dijo que con eso no se hacen chistes $)^{9}$. Puede decirse que la mejor prueba de la popularidad del romance "Arrojóse el mancebito...", con su outrageous

${ }^{9}$ Luis G. Alonso Getino, Anales salmantinos, t. 2, Salamanca, 1929, pp. 297-298, publica la glosa del maestro Uceda, contemporáneo de fray Luis de León. Cf. también Gerónimo Porras, "A un Crucifijo, cuya sagrada imagen pareció sensible, quexándose y vertiendo sangre a los açotes que le dieron unos judíos en Madrid" (Rimas varias, Antequera, 1639, f. 88r): " .. . desde el sacro cabello hasta la planta / llamó a congregación de cardenales". El chiste de los cardenales venía repitiéndose desde tiempo atrás en textos no religiosos: H. R. Bershas, "Cardenales: the case history of a pun", RPh, 9 (1955-1956), 23-26, comienza con una cita de Fernán Pérez de Guzmán y termina con una de Enrique Jardiel Poncela. 
comentario final sobre los desdichados amantes que murieron como huevos, él pasado por agua y ella estrellada, es ver cómo aprovechó Cáncer el chiste aplicándolo a Santo Domingo de Guzmán, en cuya frente apareció una estrella milagrosa cuando lo bautizaron: ". . y al ille a passar por agua / vieron que estava estrellado" 10 .

He aquí un breve muestrario de esos chistes: (1) Góngora compara a Santa Teresa de Ávila (cuyos apellidos eran Cepeda y Ahumada) con el célebre obispo de Ávila, Alonso de Madrigal, apellidado "el Tostado": “...pues abulenses los dos, / ya que no iguales en letras, / en nombre iguales, él fue / Tostado, Ahumada ella"'. - (2) Lope de Vega, en un soneto sobre el mártir San Lorenzo, se dirige a los ángeles del cielo: "Poned limpia la mesa a Cristo, y coma... ": ique le preparen un buen banquete de cordero asado a la parrilla! Y termina: “Ángeles, si la mesa le habéis puesto, / decidle que la carne coma aprisa, / que el más cristiano rey espera un hueso"' (porque Felipe II había pedido a Roma una reliquia de San Lorenzo). - (3) En una comedia religiosa de Damián Salucio del Poyo hay una riña de muchachos entre el buen Juan (que luego será el Bautista) y el malvado Grismas (o sea Gestas, el futuro Mal Ladrón): “ ¡Mas que os rompa la cabeza!", dice Grismas; y Juan responde con gran mansedumbre: "Ser mi cabeza partida / no puede, aunque yo quisiera, / porque se ha de dar entera / por postre de una comida'. (4) Aludiendo al martirio de San Juan Evangelista en la tina de aceite hirviendo, dice Alonso de Ledesma: “...y siendo tal el manjar, / no ha de faltar, a fe mía, / quien en azeyte le fría / para que pueda durar". - (5) Dice Quevedo que no es raro que el gallo haya cantado cuando San Pedro negó a Cristo: es muy natural "ver el gallo cantar por la gallina"11. - (6) Fray Damián Cornejo cuenta así uno de los milagros de San Diego de Alcalá: "De la cabeza una herida/ curó al Príncipe sangrienta: / igran cosa, a un señor quitarle / lo que tiene en la cabeza!" - (7) Sor Juana registra con insuperable economía de palabras dos hazañas de San Pedro: "Contra Maleo arguye en ferio / y en celarem con la ancila"'12. - (8) Por último, he aquí la perfecta

${ }^{10}$ Sobre esta y otras aplicaciones "religiosas" del chiste de los huevos véase mi "Fortuna varia", pp. 492-494 y 497.

${ }^{11}$ Chiste muy difundido: véase lo que dice M. Chevalier en NRFH, 36 (1988), p. 1074, nota 11

12 Desgraciadamente, es de los chistes que en nuestro siglo necesitan explicación (y a los chistes explicados se les va mucho de su chiste). El villanci- 
redondilla del Negrito Poeta acerca de la Virgen María: “A ésta lo que más le abona / es el haber concebido / sin saberlo su marido / y por tercera persona"13.

El Polifemo de Góngora fue el punto de arranque de toda una serie de fábulas mitológicas "serias", de tono elevado, compuestas en octavas reales. Baste pensar en los dos Orfeos - el de Jáuregui y el de Lope-Montalbán-, en el Faetón de Villamediana, el Hero y Leandro de Bocángel y el Minotauro de Cáncer. Entra también aquí la Filomena (1621) de Lope de Vega, una de sus largas, larguísimas fábulas mitológicas. Pero la Filomena está dividida en dos partes, la primera en las canónicas octavas y la segunda en silva. Este españolísimo metro, inexistente en el siglo XVI, se había cocinado con pasmosa rapidez en el primer decenio del XVII, y en 1613 estaba ya en su punto, como lo muestran las Soledades de Góngora, poema que inauguró la "fase imperialista" de la silva. Lope se rindió en 1621 a "los encantos de la nueva modalidad métrica" porque era ya imposible no hacerlo ${ }^{14}$. E inmediatamente comenzaron a aparecer, en competencia con las fábulas en octavas, las fábulas en silva: así el Fénix de. Villamedia-

co que contiene esos versos presenta a San Pedro como el alumno estrella de una clase universitaria de Lógica; así, en una disputa escolástica argumentó muy bien utilizando dos de los esquemas de silogismo resumidos en los hexámetros mnemotécnicos Barbara Celarent Darii Ferio Baralipton...: a Malco lo hiere (Ferio) con la espada y le corta una oreja; a la ancila, o sea a la criada de Caifás, le oculta (Celarem) que él es uno de los que andan con Jesús. (A propósito de la oreja de Maleo: un siglo antes de Sor Juana, censurando a ciertos individuos que se las dan de graciosos, decía DAMASIO de Frías, Diálogos, Madrid, 1929, p. 156: "Estaréis con hombres de éstos tratando de la Pasión de Cristo, y allí procurarán haceros reír con la cuchillada que dio San Pedro al otro desorejado".)

${ }^{13}$ En nuestros días tal vez sólo un católico relativamente bien instruido entiende la alusión, por una parte, a la maternidad virginal de María (y a la consiguiente perplejidad de San José, su marido), y por otra a la acción de la Tercera Persona de la Santísima Trinidad, o sea el Espíritu Santo. La redondilla está en Rubén M. Campos, El folklore literario de México, México, 1929, p. 93. El Negrito Poeta es un personaje semilegendario del siglo xviII. La redondilla bien puede ser "anónima", venida de tiempos anteriores e incorporada a la tradición oral. Es seguro que muchas "irreverencias" se transmiten de boca en boca y de generación en generación. He aquí un ejemplo de mi folklore infantil y pueblerino: "Padre nuestro que estás en los cerros, / tú cuida las vacas y yo los becerros"; y otro: "Santa Regina / mató su gallina; / gimiendo y llorando / la estuvo pelando...".

14 Véase E. Asensio, "Un Quevedo incógnito: las silvas", Edad de Oro, 
na y el de Pellicer, la Anaxárete de Manuel Gallegos, el Alfeo de Colodrero de Villalobos y el Adonis de Soto de Rojas. Finalmente, la silva no tardó en engendrar una subespecie que resultaría muy atractiva: la silva de versos pareados, llamada a veces ovillejo (u ovillejos) $^{15}$. Ya la neo-mitológica Fábula de Galia y Flaminio (1624), de Manuel de Faría y Sousa, lo mismo que el mencionado Alfeo de Colodrero, son silvas con gran mayoría de pareados. Pero no conozco ninguna fábula "seria" hecha totalmente en pareados, salvo el muy tardío Caos (1688) de Juan Bautista Aguilar (el adicionador del Theatro de los dioses de Baltasar de Vitoria).

La métrica de las fábulas burlescas tiene una historia distinta. Durante los primeros tiempos el único metro que se utilizó fue el de los Leandros y los Píramos de Góngora, o sea el romance. Pero en 1624 publicó Castillo Solórzano un Pollfemo burlesco en octavas ("Estas que me dictó rimas burlescas / jocosa, si no culta, Musa mía... '), en 1629 apareció la divertida Fábula de las tres diosas (el Juicio de Paris) de Gabriel de Corral, en silva "normal", y en 1631 la "historia burlesca" de Hero y Leandro, por don García de Medrano y Barrionuevo, que comienza así:

No la pido a mi voz que el mundo atruene, ni yo quiero que suene. Óiganla pocos, que aunque ronca mi voz, no tiene mocos. Sólo quiero que traiga a la memoria de dos dulces amantes una historia tan agria, que al ministro más severo le obliga a ser gestero.

Tampoco he de invocar Musa ni Muso, por no entrar en el uso.

Allá se estén las Musas con su Apolo, que el coronista quiero ser yo solo.

Érase, pues... (con érase he empezado: principio de consejas he tomado)...

Salvo el verso inicial, todos los demás, hasta el último, van de dos en dos: cada oveja con su pareja. Éste es el metro de las fábulas burlescas de Apolo y Leucotoe por Gabriel de Herrera, de Acteón

2 (1983), 13-48. (De ahí, pp. 31 y 33, son las frases entrecomilladas.) Véase también A. AlatorRe, "Quevedo: de la silva al ovillejo", HEA, pp. 19-31. Asensio y yo estudiamos el papel de Quevedo en la creación de la silva, pero sin olvidar el papel de sus contemporáneos.

${ }^{15}$ Sobre los orígenes de esta subespecie véase mi “Quevedo...", pp. 27-30. 
y Diana por Melchior Zapata, de Hero y Leandro por Sebastião de Fonseca e Paiva (en portugués), y de la Fábula de Diana de fray Antonio de San José ${ }^{16}$.

La Fábula de Apolo y Dafne de Polo de Medina, publicada en 1634, o sea tres años después del Hero y Leandro de Medrano, merece un lugar aparte. No es una silva de pareados perfecta (a lo largo del poema, desparramadas aquí y allá, hay ovejas sin pareja, o sea versos sueltos), pero fue el modelo indiscutible de gran número de fábulas posteriores. Con ella fijó Polo "una fórmula original de elaboración de este género de poemas" (Cossío, p. 680). He aquí una breve muestra del comienzo:

Cantar de Apolo y Dafne los amores sin más ni más me vino al pensamiento [...]. Érase una muchacha con mil sales, con una cara de a cien mil reales, como así me la quiero; más peinada y pulida que un barbero [...]. Aquí es obligación, señora Musa, si ya lo que se usa no se excusa, el pintar de la ninfa las facciones...

Conviene señalar - aunque salte a la vista (o al oído) - que el gracejo, el tono de broma, se ajusta maravillosamente a este metro juguetón, hace con él un matrimonio perfecto. Así había sucedido desde los orígenes de la silva de pareados. Varios de los más chistosos juguetes poéticos de Quevedo (epigramas, epitafios, etc.) están escritos en pareados. A Quevedo, por cierto, se atribuyeron tres poemas burlescos de dimensiones considerables y que tuvieron merecida fortuna, compuestos los tres en silva de pareados: Los Ejercicios de San Ignacio ( = La penitencia de los teatinos), que es de Juan de Salinas, el Epitalamio burlesco "Ven, Himeneo, ven, honra este día...", que es de Rodrigo Fernández de Ribera, y La cueva de Meliso, que es de Francisco de Rioja ${ }^{17}$. La atribu-

16 Todo esto está dicho muy esquemáticamente. El metro predominante de las fábulas mitológicas (así serias como burlescas) fue siempre el romance hasta muy entrado el siglo xviII, y por otra parte siguió habiendo fábulas burlescas en silva "normal", como el Hermafrodito de Antonio de Solís.

${ }^{17}$ Sobre los dos primeros véase mi "Quevedo. ..", pp. 29-30 (el Epitalamio está en las eds. de Astrana Marín y de Blecua; Los Ejercicios de San Ignacio, sólo en la de Astrana). Para La cueva de Meliso (cuyo asunto es la caída de Olivares), véase $B A E$, t. 69, pp. 543-552, y RHi, 72 (1928), 303-321. Cosa curiosa: los tres verdaderos autores - Salinas, Fernández de Ribera y Rioja - eran sevillanos. 
ción a Quevedo es muy comprensible, pues en los tres poemas sobresale esa gran especialidad suya que es $e l_{\text {c }}$ chiste a toda costa, el constante guiño de ojos dirigido al lector. Pero quien luego se alzó con la monarquía de esta especialidad fue Polo de Medina, famosísimo durante todo el resto de la era barroca. Es muy significativo que Cossío, pp. 691-692, deslumbrado por el brillo de esa monarquía, creyera que uno de los primeros imitadores de Polo fue Medrano, pese al hecho evidente de que el Hero y Leandro de Medrano se imprimió tres años antes que la Dafne.

Esta Dafne es la única fábula que compuso Polo en silva de pareados (las otras están escritas en romance); pero escribió asimismo una serie notable de composiciones festivas - "A una dueña muy golosa", "Un poeta llorando sus pecados poéticos", "A una vieja que murió de dentera de comer limón", "Retrata un galán a una mulata, su dama”, etc.- que están todas en pareados más o menos entreverados con sueltos y que constituyen, con la Dafne, el estilo por excelencia de Polo de Medina. Desde el primer verso hasta el último avanzamos de sorpresa en sorpresa, asaltados por toda clase de agudezas y conceptos: retruécanos, metáforas inesperadas, símiles descabellados, anacronismos, juegos de palabras, refranes, frases hechas, muletillas, modismos, autoburlas, citas paródicas de versos conocidos, saltos de lo culto a lo vulgar... Pero las "vulgaridades', de Polo se quedan siempre dentro de los límites de lo urbano. Él nunca se pasa de la raya. La obscenidad de Quevedo le es ajena. Sus chistes invitan a la sonrisa, no a la carcajada. A esa estirpe poética pertenecen no sólo varias de las fábulas burlescas que he mencionado, como el Acteón de Zapata ${ }^{18}$, sino también muchos otros divertimientos cuyo más exquisito representante es el Retrato de Lisarda ("El pintar de Lisarda la belleza...") de Sor Juana Inés de la Cruz, hecho, como dice el epígrafe, "en jocoso numen, igual con el tan célebre de Jacinto Polo"'19. Las composiciones hechas en este numen pe-

${ }^{18}$ Que comienza así: "Fábula va, señores, que la arrojo, / y que les llene o no les llene el ojo, / porque yo no me meto / más que en echarla, como lo prometo [ . . . / / Y nadie ponga dolo / en que esto es imitar a cierto Polo /Jacinto Salvador con su Medina, / porque también mi Musa, si se empina, / es de las empinadas / y de las muy también vulgarizadas. / Érase (y aunque hay érase no es cuento)...", etcétera.

${ }^{19}$ Dice Sor Juana, vv. 135-140: “ ¡Ay con toda la trampa/que una Musa del hampa, / a quien ayuda tan propicio Apolo, / se haya rozado con Jacinto Polo / en aquel conceptillo desdichado, / y pensarán que es robo bien pensado!"' 
dían un declamador (o declamadora) con mucho salero, y una tertulia de gente desocupada ${ }^{20}$, inteligente y buena apreciadora. Los autores, muy conscientes de su obligación de tener divertido al auditorio, todo el tiempo llueven gracias sobre él. La tertulia poética del Barroco debe haberse parecido a un concierto de música de cámara.

Estos poetas debían responder airosamente a tres retos principales. En primer lugar, como se dirigían a expertos, tenían que hallar chistes nuevos, agudezas nuevas. Si se piensa, por ejemplo, en la cantidad de fábulas burlescas que se hicieron sobre Vulcano, sobre Acteón, sobre Dafne, sobre Siringa, el reto de la novedad era muy serio. No menos serio era este reto en lo referente a las imágenes y el vocabulario. En su Retrato de Lisarda se queja Sor Juana no sólo de que todo está dicho, sino de que las maneras de decir están ya agotadas. Cuando les llega el turno a las cejas de Lisarda, nos expone paladinamente el problema: cejas muy bien arqueadas, sí, y de allí una alusión al arco de Cupido, o bien al arco que serenó el Diluvio... ¡Pues no! ¡Esas cejas son la cañería o arcaduz que lleva el agua a los ojos cuando Lisarda está de morros! (" ¿Esto quién lo ha pensado? / ¿Me dirán que esto es viejo y ya trillado?' $)^{21}$.

El segundo reto es: no mezclar géneros. A partir de cierto momento se exige no salirse de la línea burlesca. Al describir la frente de Lisarda, Sor Juana se hace un verdadero lío: dice primero que es tan amplia, que bien medirá una caballería o más; luego nos pone en guardia: no pensemos en una tierra arada (frente con arrugas), ya que "estas caballerías son del cielo"; añade entonces: "¿Qué apostamos que ahora piensan todos / que he perdido los modos / del estilo burlesco?', e inmediatamente

${ }^{20}$ Las academias barrocas, donde poetas de dimanche se codeaban con profesionales, solían adoptar nombres sonoros: la Academia Salvaje, la Extravagante, la de los Desconfiados, la de los Humildes, la de los Singulares. Bien hubieran podido todas ellas tener el nombre de la que en 1610-1616 se reunía en Nápoles en el palacio virreinal del Conde de Lemos: Academia de los Ociosos.

${ }^{21}$ Lo mismo vale, por supuesto, para la poesía seria. La descripción de las mejillas de la dama pedía una pugna de lo rojo y lo blanco; pero el repertorio de imágenes, rosa/azucena, clavel/jazmín, etc., no era ilimitado. Sor Juana, en su retrato de la Condesa de Calve ("Con los héroes a Elvira..."), dice que "Alencastro y Ayorque / son sus mejillas", o sea que en ellas tiene lugar la Guerra de las Dos Rosas, la roja de Lancaster y la blanca de York (imagen novedosísima, seguramente única en la poesía barroca de lengua española). 
explica (con patentes sofismas) que no ha violado las reglas. (Polo de Medina se las había arreglado para convertir en broma una intromisión de lo serio: después de decir que Dafne "puso pies en polvorosa" cuando Apolo iba a desmandarse, no puede evitar este verso: "exhalación corrió de nieve y rosa", y en seguida comenta: "¡Pésiate tal, qué lindo verso he dicho!").

El tercer reto es: evitar el ripio, la palabra vacía, a-poética (sin creación), la rima metida sin más razón que servir de apoyo a otra, que es la que importa 22 . Este reto es insidioso sobre todo en el caso de la silva de pareados, donde las rimas van constante y descaradamente juntas. Polo de Medina tiene dos maneras de salir del paso: una es agarrar el ripio por los cuernos, y así, después de decir, en su descripción de los ojos de Dafne, que "de la Etiopia son sus niñas bellas", se dirige a los lectores (u oyentes): 'Sí, ya sé lo que están pensando ustedes: que la rima va a ser estrellas'; la otra manera, más sencilla, es meter aquí y allá versos sueltos, versos de descanso, padrenuestros intercalados en el rosario, preservativo contra la potencial somnolencia de la ristra de pareados $^{23}$.

\section{El poeta Miguel de Barrios}

Miguel de Barrios nació en el seno de una familia de "conversos" en Montilla (provincia de Córdoba) ${ }^{24}$, donde fue bautizado el 3 de noviembre de 1635. Es claro que se crió como cristiano ${ }^{25}$,

22 “ ¡Fuerza del consonante, a lo que obligas!”. . ¿Puede admitirse que por necesidades de rima la ilustre matrona Lucrecia resulte ser una necia? La prueba del buen poeta es no dar señales de haber sucumbido a la fuerza del consonante. Un buen lector (u oyente) percibe esas cosas y tiene derecho a protestar: “Esto es ripioso!” Y los poetas, aun los buenos, siempre les han tenido miedo a los buenos lectores.

${ }^{23}$ Los poetas posteriores a Polo renunciaron valientemente a esta "licencia". De ahí ciertos problemas, como el de Sor Juana en los vv. 147-150 de su Lisarda: " Jesús, qué mal empiezo. . .! / (Principio iba a decir, ya lo confieso, / y acordéme al instante / que principio no tiene consonante. / Perdonen, que esta mengua / es de que no me ayuda bien la lengua)".

${ }^{24}$ En su poema "De la fértil Andalucía" dice Barrios que Córdoba "tres ciudades espléndidas domina, / y mi patria Montilla es la primera" (Scholberg, p. 51). De Scholberg proceden todos los datos biográficos que siguen.

${ }^{25}$ A diferencia de João Pinto Delgado, el cual "fue criado en el judaísmo clandestino desde temprana edad", en Lisboa (OELman, p. 185). 
pero también es claro que ni él ni su familia lo fueron muy en serio. Un joven pariente, Marcos de Almeida, alias Ishac de Almeida Bernal, natural asimismo de Montilla, cayó hacia 1650 en las garras de la Inquisición (y murió en la hoguera en 1655). No mucho tiempo después, los Barrios salieron de España. Los padres y algunos de los hijos se radicaron en Argel, y Miguel emigró primero a Niza y luego a Livorno, donde desde tiempo atrás había una comunidad judía bien establecida. Aquí, guiado por una tía suya, Miguel "se convirtió" y se hizo circuncidar ("A mi tía Raquel Coén de Sosa / debo la primer luz de la Ley pura', dirá en un poema). En 1660 se trasladó a la antillana Tobago, posesión holandesa, con ánimo de establecerse; pero inmediatamente (en 1661) regresó, no a Livorno, sino a Amsterdam, o tal vez a Bruselas. Lo cierto es que durante mucho tiempo estuvo oscilando entre estas dos ciudades y llevando una doble vida: en Bruselas callaba su historia y figuraba, aparentemente sin problemas, como católico; en Amsterdam era judío y se llamaba Daniel Levi de Barrios (el nombre del abuelo paterno era Abraham Leví Caniso [¿o Cansino?]).

Todo parece indicar que, por más esfuerzos que hizo, Barrios nunca se integró del todo a esa comunidad judía de Amsterdam compuesta en gran parte por individuos nacidos ya allí, muy desconectados de España y de los moldes españoles de pensamiento, o sea cada vez menos españoles y cada vez más europeos. Sus peculiaridades y sus problemas se explican básicamente por esta "desventaja" de origen.

Barrios fue uno de los muchos judíos de Amsterdam que pusieron toda su fe en el "Mesías" Sabbatái Zeví, y que aun después del horrible fiasco de 1666 siguieron creyendo fervientemente en él, hasta que se hizo imposible cerrar más los ojos. Los demás no tardarían en olvidar el asunto, pero la decepción de Barrios debe haber sido tremenda, a juzgar por la intensidad de la "crisis" de 1674: en la Pascua de este año estuvo durante días como loco, sin probar bocado, asediado por visiones extrañas. "Se recuperó del delirio, pero su equilibrio mental quedó siempre en estado precario" (ScHOlBERG, pp. 24-25). La "crisis", acompañada de alucinaciones y otros trastornos, se repitió en años subsiguientes, por ejemplo en 1682 y en 1685 (ID., pp. 29 y 36).

Oelman, p. 201, relaciona la "enfermedad mental" de Barrios con su modo "esquizofrénico" de vida, entre Amsterdam y Bruselas. Es un hecho que nunca rompió su relación con la 
cristiandad. Desde su llegada a los Países Bajos lo vemos lisonjeando por una parte a miembros prominentes de la comunidad judía, y por otra a protestantes poderosos y aun a "los magnates españoles y portugueses" (ScholberG, p. 19). Los elogios a príncipes cristianos continuaron durante su época más declaradamente judía (ID., pp. 31 y 37 , años 1683 y 1686$)^{26}$. Es muy significativo lo que ocurrió en 1679, cuando murió su amigo Tomás de Pinedo. Él y Pinedo tenían amigos comunes en España, uno de los cuales, el erudito Gaspar Ibáñez de Segovia, le escribió a Barrios diciendo que sentía la muerte de Pinedo, y que le dolía saber que había muerto en la religión judaica, "habiéndose criado entre católicos". Barrios, mostrándose muy herido, "le contestó en dos sonetos ardientes que no dejaron lugar a dudas sobre su propia religión" (ID., p. 29; texto en las pp. 237-238) ${ }^{27}$. Significativas son también estas palabras de una carta suya al rey Luis XIV: "Soy español, y tócame (ya que no puedo con la espada) manifestar con la pluma que a mi Rey por divino decreto debe Vuestra Real Majestad restituir el ducado de Borgoña" (ID., p. 31). Puede sorprender que en 1686, año en que escribió esas palabras, se considerara Barrios súbdito activo de Carlos II; pero no sorprende que se definiera como escritor español. Esto no se le podía quitar ni aunque lo hubiera querido. Escritor español fue hasta su muerte, ocurrida en 1701.

${ }^{26}$ Quizá en el escenario europeo del siglo Xvir hayan quedado vestigios de las corrientes iremistas del xvr. Uno de los reformadores "radicales", Giacomo Massilara (Jacobo Paleólogo), escribió un tratadito De tribus gentibus (Cracovia, 1572) en el cual decía que cristianos, judíos y musulmanes - las tres gentes del título- adoraban a un solo y mismo Dios y eran en consecuencia hermanos: las cosas que los separaban eran accidentales. Por ejemplo, ¿qué tal si los cristianos, en plan de entendimiento, reflexionamos en lo que nuestros hermanos judíos y mahometanos declaran "inaceptable", como la Trinidad y la Eucaristía, y reconocemos que en efecto la doctrina de la Trinidad es adventicia (y eliminable) y les aclaramos que la Eucaristía es una simple costumbre, una cena conmemorativa, un acto social? (GEORGE H. Willilams, La Reforma radical, trad. A. Alatorre, México, 1983, pp. 817-818 et passim: véanse en el índice las voces "sabatarios", "unitarismo" y "universalismo".) ¡Ah, si hubiera podido convertirse en realidad ese sueño de tolerancia, de convivencia pacífica, de vida civilizada!

${ }^{27}$ En este episodio hay un elemento tramposo: ¿qué culpa tenía Ibáñez de Segovia en pensar que Barrios y Pinedo eran católicos? Ellos nunca le habían dicho otra cosa. Por lo demás, es evidente que el conocimiento que se tuvo en España de las juderías europeas fue muy superficial. 
Barrios "parece haber absorbido todas las influencias del culteranismo y del conceptismo", dice Oelman, p. 201. A diferencia de quienes se fueron a Argel o al imperio otomano, los judíos que a lo largo del siglo xvil pasaron a los Países Bajos nunca dejaron de tener acceso a las novedades españolas de librería. Los que manejaban la pluma, como Barrios, no sólo estaban al corriente en cuanto a literatura española, sino que siguieron siendo, durante largos decenios, parte de ella. Y los escritores no fueron pocos ${ }^{28}$. Uno de ellos, el entusiasta Manuel de Belmonte, fundó en Amsterdam dos academias sucesivas en que se leían composiciones en español, la de los Sitibundos en 1676 y la de los Floridos en 1686, y Barrios estuvo presente en una y otra (Scholberg, pp. 20, 34 y 73). Se puede hablar, pues, de una auténtica vida literaria, aunque, desde luego, menos activa que la de ciudades de lengua española. Había escritores, había impresores y había lectores. La nutrida producción de Barrios, cuya lista da Scholberg en las pp. 351-353, tenía obviamente un público.

Su primera obra impresa, Flor de Apolo, apareció en Bruselas en 1665. No se distingue gran cosa de los libros de versos que se publicaban en España ${ }^{29}$. Ni siquiera es de llamar la atención la presencia de poemas de tema bíblico, pues los temas bíblicos no son raros en los poetas españoles cristianos. Pero si las poesías profanas (amorosas, mitológicas, panegíricas, etc.) no parecen haber suscitado reprobación alguna, como materia "indiferente" que eran, otra cosa pasó con las de tema bíblico. He aquí un detalle mínimo y muy revelador: en el romance "A Olofernes y Judic" Barrios llama a Holofernes "el babilonio Cid", lo cual escandalizó a los ortodoxos (Scholberg, p. 45), enemigos de estos mestizajes poéticos.

Se tiene la impresión de que Barrios era considerado "sospechoso en la fe" por los dirigentes de la comunidad judía, y de que, para quitarse el estigma, escribió una gran comedia alegórica en celebración de tres "santos" judíos, tal como Mateo Ale-

${ }^{28}$ La más copiosa fuente de información bibliográfica acerca de estos escritores sigue siendo MAYER KAYSER LING, Biblioteca española-portugueza-judaica, Strasbourg, 1890. Barrios mismo escribió una "Relación de los poetas y escritores españoles de la nación judaica amstelodama" (ScrolberG, pp. 30 y 72).

${ }^{29}$ Pero a los poetas españoles les deben de haber causado envidia las magníficas ilustraciones (dibujadas por A. Dipenbeke y esculpidas en bronce por P. Clouwet) que acompañan a seis de las fábulas mitológicas: Alfeo, Polifemo, Calisto, Narciso, Vulcano y Adonis. 
mán parece haber escrito su San Antonio de Padua para acallar las sospechas de criptojudaísmo que sobre él pesaban. El título completo de la comedia, escrita "antes de 1672" e impresa en Amsterdam, es: Contra la Verdad no hay fuerça: Panegirico a los tres bienaventurados mártires Abraham Athías, Jahacob Rodríguez Casares y Raquel Núnez Fernández, que fueron quemados vivos en Córdova, por santificar la Unidad. Divina, en 16 de Tamuz, año de 5425. ¡Tan "judío" todo, hasta la fecha del martirio, equivalente en el calendario cristiano a 25 de junio de 1665 ! Pero no fue ése el sentir de los censores, los cuales cortaron por lo sano y suprimieron la comedia, "según parece, antes que pudiera ponerse en circulación" (SCHOl.Berg, p. 110). No se conservan sino tres ejemplares, y en los tres están arrancadas las 16 páginas que contenían la loa, seguramente por ser ésta lo más escandaloso.

Tras esto vino el Coro de las Musas, libro de la misma índole "inofensiva" que la Flor de Apolo, aunque mucho más voluminoso, publicado en 1672 "en ediciones gemelas" de Bruselas y de Amsterdam ${ }^{30}$. Como en seguida veremos, también el Coro fue censurado por los ortodoxos.

La Flor de Apolo y el Coro de las Musas existen en muchas bibliotecas, y "son las obras que tienen en mente los críticos cuando hablan de la poesía de Barrios", mientras que las que vinieron después "han quedado casi desconocidas" (ScholberG, p. 56). A ellas - y a la comedia de La Verdad- dedica Scholberg su excelente libro, La poesía religiosa de Miguel de Barrios, comenzando con el Imperio de Dios en la harmonía del mundo, libro que Barrios prepa-

${ }^{30}$ Se trata en realidad de una sola edición, pero en una parte de ella figura como impresor el belga Baltazar Vivien (Bruselas) y en la otra el marrano Juan Luis de la Paz (Amsterdam). El Coro se divide en nueve secciones, dedicada cada una a una de las Musas. Era costumbre muy española. El ejemplo más conocido es el Parnaso español (1648), o sea la obra poética de Quevedo editada por González de Salas. Lo habían precedido por lo menos dos libros: el San Ignacio del jesuita Antonio de Escobar y Mendoza (Valladolid, 1613), "poema heroico" dividido en siete cantos "dedicados a siete Musas, ya que excluye a Erato y Talía porque favorecen los cantos lascivos" (según I. Elizaldo en AHSI, 25, 1956, pp. 233-237) y los Favores de las Musas de Sebastián Francisco de Medrano (Milán, 1631). Análoga disposición tienen, después, las Obras métricas de Francisco Manuel de Melo (Lyon, 1665), las Delicias de Apolo de Francisco de la Torre Sevil (Madrid, 1670) y la Cima del monte Parnaso de José Delitala (Cáller, 1672). Quien puso en 1689 el título de Inundación Castálida al primer tomo de las obras de Sor Juana (y que seguramente no fue ella) pensaba en una invasión tumultuaria de todas las Musas y no dividió el volumen en nueve secciones. 
raba en 1672, pues lo menciona varias veces en el Coro. Se iba a llamar Parnaso del Cielo - como si dijéramos Coro de las Musas "a lo divino" - , pero es evidente que aun el título disgustó a los quisquillosos, y Barrios tuvo que despaganizarlo. Su intención era, nada menos, "componer una versión poética del Pentateuco" (Scholberg, p. 98), o sea de la venerable Torah, de "la Ley". Esto suponía no sólo lectura de la Torah, sino también una "postura" ante ella, una visión, una interpretación. Pero Barrios carecía del bagaje intelectual severamente judaico de coetáneos suyos como Ishac Orobio de Castro o como Juan de Prado (el amigo de Spinoza). Él había leído, probablemente desde su adolescencia en Montilla, a Góngora, Lope, Quevedo, Polo de Medina, Calderón... (y también a Camoens). Su obra tiene el inconfundible sello barroco o más bien ultrabarroco de la literatura española (cristiana) de la segunda mitad del siglo xvı. "Si vemos el conjunto de su poesía, parecería que se dio a la tarea de poner al servicio de su judaísmo todos los artificios de ese estilo, incluyendo sus excesos"' (Oelman, p. 205), lo cual no podía sino repugnar a los ortodoxos. A comienzos de 1673 le escribía Barrios a un tío suyo: "Ninguna de las obras que di a la estampa fue tan criticada como ésta [el Coro de las Musas] y la que estoy imprimiendo, intitulada Harmonía del mundo" (SCHOLberG, p. 102). Como se ve, las censuras empezaron antes de la publicación del libro, y cuando éste se imprimió en Bruselas "hacia 1673" (ibid.), los dirigentes de la comunidad de Amsterdam lo prohibieron, diciendo "ọue en la composición aparecían nombres que no se hallan en nuestra Tora, y también que convertía nuestra Tora en libro profano"' (Kayserling, apud ScholberG, p. 99).

Salta a la vista el empeño que puso Barrios en mostrarse más judío en sus libros posteriores, como el Sol de vida (1679), el Libre alvedrio (1680), el Triumpho del govierno popular (1683), los Dias penitenciales (1685) y la Estrella de Jacob (1686). Y es conmovedor ver cómo, cada vez que puede, mete en estos escritos algunas palabras o frasecitas en hebreo. Pero su modo de pensar siguió siendo básicamente cristiano.

Según lo ponen de relieve sus "crisis" de locura, Barrios es el paradigma mismo de esas "almas en litigio" (gespleten zielen) estudiadas con amor por J. A. van Praag ${ }^{31}$. Las dos fuerzas

${ }^{31}$ J. A. VAn PRaAG, "Almas en litigio", Clavileño, 1950, núm. 1, pp. 25 s.s. En su artículo "Sobre el sentido del Guzmán de Alfarache", EMP, 5 (1954), 283-306 [reseñado por mí en NRFH, 13 (1959), p. 135], dice van Praag que 
internas de este nouveau juif, el amor a la dicción poética española y la voluntad de abrazar de lleno la religión de Israel, están siempre chocando con dos fuerzas externas, la hostilidad de España a todo lo judío y la suspicacia de los judíos por un neófito tan lleno de resabios cristianos ${ }^{32}$. El único escritor marrano que "parece haberse liberado de los residuos de influencia cristiana" fue Pinto Delgado (Oelman, p. 187). La religiosidad judía de Barrios se expresa en lenguaje cristiano. Habla de "fe en la Ley" como los cristianos de "fe en Cristo", y aun en sus poemas más judíos se percibe "una comparación subyacente entre judaísmo y cristianismo" (ibid). Así, cuando glosa la popularísima octava "Yo ¿para qué nací? Para salvarme... ", cuyo verso 8 dice "Loco debo de ser, pues no soy santo" (ScholberG, pp. 157-158; y cf. Gracián, Agudeza, discurso XLIII), Barrios "no hace ningún intento por inyectar algún elemento judaico" (Oelman, p. 203). Sus Días penitenciales ${ }^{33}$ bien hubieran podido rotularse Dias cuaresmales. Entre ese libro y el Heráclito cristiano de Quevedo no hay muchas diferencias. Claro que si los versos de Barrios, "Hoy a tus plantas, mi Criador, postrado, / postrar procuro mi delito fiero", hubieran sido escritos por Quevedo, no significarían 'Perdóname, oh Dios de mi pueblo, por haber llevado tanto tiempo una vida no de judío, sino de cristiano' (como dice Barrios en otro lugar: "Gran pesar tengo de no haber tenido / firme observancia de tu Ley segura"), sino que significarían más bien 'Me duele no haber sido hasta ahora un buen cristiano' (como dice Quevedo en otro lugar: "Un nuevo corazón, un hombre nuevo / ha menester, Señor, la ánima mía"). Mucha de la poesía religiosa de Barrios no se distingue prima facie de la poesía católica. Composiciones como el "Acto segundo de contrición" (de los Días penitenciales) están amasadas en sentimientos acendradamente cristianos. Un católico está en su elemento al leer, por ejemplo (ScholberG, pp. 172-174): “¡Oh cuántas

Mateo Alemán fue una de esas "almas en litigio", tan marrano como los que emigraron a los Países Bajos.

${ }^{32}$ A los esfuerzos de Barrios por hacerse aceptar hay que añadir sus escritos acerca de asuntos prácticos, por ejemplo sobre "la organización de la vida pública de los sefardíes" (ScholberG, p. 70), y también un plan de Historia universal judaica que iba a constar de cinco volúmenes, si bien no pasó del prospecto, impreso en 1684.

${ }^{33}$ En la liturgia judía se llaman así "los diez días entre Rosh Hashaná y Yom Kipur, y son un período de introspección y purificación espiritual en que se prepara el creyente para expiar sus pecados en la más sacra de las fiestas hebreas, el Día del Perdón" (ScholberG, pp. 93-94). 
veces pequé! / ¡Oh cuántas lo siento! ¡Oh cuántas, / por no llegar a tus plantas, / a las del error llegué!...' (y tendrá ante los ojos un devoto Crucifijo, mientras que Barrios se dirige al Dios de Israel)"34; y cuando el lector católico llega a los versos "Confieso que idolatré, / que me manché en la agua inmunda...', entiende que amó bellezas fementidas y estuvo hundido en el pecado, mientras que Barrios entiende algo muy concreto: 'Me duele haberme arrodillado en templos católicos, me duele haber sido bautizado'.

A imitación del propio Barrios, que en cierto "sermón" incluye un soneto de Lope de Vega sustituyendo el segundo terceto por uno propio (ScholberG, p. 72), voy a poner aquí dos sonetos hechos "en colaboración" por Quevedo y Barrios, retando al lector (salvo si es muy versado en Quevedo) a adivinar, en cada caso, de quién son los cuartetos y de quién los tercetos (las partes correspondientes a Barrios están en Saholberg, pp. 177 y 226):

¡Cuán fuera voy, Señor, de tu rebaño, llevado del antojo y gusto mío! Llévame mi esperanza el tiempo frío, y a mí, con ella, un disfrazado engaño.

Un año se me va tras otro año y yo, más duro y pertinaz, porfío por mostrarme más verde mi albedrío la torcida raíz do está mi daño.

En este del pecado Argel impío me confieso, ante $\mathrm{Ti}$, cautivo suyo: más que en mi confesión, en Ti confío.

¡Piedad, Señor!, que de mí propio huyo, procurando en tu gracia no ser mío por merecer la gloria de ser tuyo.

II

Es un forzoso tránsito la muerte, natural desengaño de la vida; es lo más cierto y lo que más se olvida; es lo menos temido y lo más fuerte;

${ }^{34}$ En La Verdad dice el Albedrío (vv. 1539 ss.): "Arrepentido confieso, / en el tormento que paso, / que atropellé tus preceptos / por correr con mis pecados. / Seguí al Vicio (ya lo lloro)...", etcétera. 
voraz rüna de la humana suerte, del más estable término caída, reloj fatal que al alma divertida hace, con lentos pasos, que despierte.

No sentí resbalar mudos los años; hoy los lloro pasados, y los veo rïendo de mis lágrimas y daños.

Mi penitencia deba a mi deseo, pues me deben la vida mis engaños, y espero el mal que paso, y no lo creo.

Exactamente de esa índole es la compenetración de Barrios con la vertiente burlesca de la dicción poética española. Su afición a la agudeza, al chiste, es incontenible. De sus nueve fábulas mitológicas, sólo una es completamente "seria": la de Eco y Narciso (escrita en estancias petrarquistas). Las de Adonis, Alfeo, Calisto, Siringa y Vulcano son descaradamente burlescas; la de Polifemo y la de Tetis son un despliegue de agudezas; y la de Prometeo y Pandora, de tono "culto", rechina a ratos con chistes bastante gruesos $^{35}$.

De manera fatal, lo burlesco tenía que meterse también en los temas sagrados. Un producto cristiano como la Vida joco-seria de Santo Domingo tiene su correspondiente en la Alabanza jocosa a la Ley santísima en la fábrica de la Sinagoga, que es un romance muy extenso (ScholberG, pp. 131-137). Veamos algunos ejemplos: (1) La Ley es una mujer muy guapa; los "jueces del pueblo" la galantean, pero están "muy celosos, / viendo que con todos anda" (por un lado, una mujer disoluta, o coqueta al menos, que con todos anda; por otro, la Ley que se entrega a todo el pueblo judío). - (2) Esa dama tiene de particular que "cuando más galanes tiene, / entonces es más honrada' (honrada '[mujer] recatada', '[Ley] venerada') ${ }^{36}$. - (3) "Algunos la traen entre ojos / y en bocas" (sentido directo: "Algunos le tienen ojeriza [a la

${ }^{35}$ Por ejemplo: "Con mal pie el dios de la fragua / se derrienga en el festejo, / que limpiándose los mocos / va reverencias haciendo"; "Dale tal susto a la novia, / que acostándose en el lecho / por persuasión de su esposo, / no cena más que unos huevos". Sobre las fábulas de Barrios véase Cos. sío, pp. 633-636 y 737-741. (Cossío, por cierto, parece no haber conocido la de Prometeo y Pandora, que falta en la Flor de Apolo, pero está en el Coro de las Musas.)

${ }^{36}$ Chiste análogo en La Verdad, donde el Apetito (el gracioso de la comedia) dice de la Ley: "yo la tengo por honrada, / pues ninguno la halló fácil", 
fulana] y dicen cosas sobre ella'; sentido figurado: 'Algunos [los judíos más piadosos] no hacen sino estudiar la Ley y comentarla'). - (4) "Aunque no es muy entendida / se precia de bien mirada, / y de hablar siempre verdad / con tener setenta caras" (en sentido directo, una dama boba, presumida y muy mentirosa; en sentido figurado, la Ley, a quien todos reverencian aunque no todos llegan a entenderla, pues si bien todo en ella es verdad, necesita ser interpretada) $)^{37}$. - (5) La Ley "disculpa" irónicamente a los Inquisidores españoles diciendo que "[son] tan niños de doctrina, / que se destetan con papas"38. - (6) "Anda por toda la tierra / tan valentona de fama ${ }^{39}$, / que solamente con serlo / deja a la gente cortada" (o sea: deja circuncidado al pueblo judío; también en La Verdadi dice el Apetito, v. 1510, que "Israel está cortado").

A las abundantes producciones poéticas de Miguel de Barrios voy a añadir ahora una más, la Fábula de Christo y la Magdalena. Encontré la primera noticia de esta fábula en el artículo de J. A. van Praag sobre el Guzmián de Alfarache, publicado en 1954 (cf. supra, p. 417, nota 31). Interesado ya entonces en el fenómeno de la fábula burlesca, le pregunté a van Praag en 1963, durante el Congreso de Hispanistas en Utrecht, que por qué no la publicaba, y él me contestó que porque era muy chocarrera y blasfema; a causa seguramente de eso el autor se había ocultado bajo un pseudónimo: "fray Antonio Márquez". Por otra parte, en 1963 estaba yo interesado en Miguel de Barrios gracias al excelente libro de Scholberg, que poco antes había llegado a la redacción de la $N R F H$ para ser reseñado, y que estuve, en efecto, a punto de reseñar ${ }^{40}$. Conocía ya, aunque no a fondo, la Flor de

(v. 2398). Otro chiste del Apetito: casarse con una vieja (v. 2387) 'jurar fidelidad a la Ley de Moisés'.

37 Scholberg explica que setenta caras es "expresión rabínica para indicar que hay una multitud de maneras de interpretar la Torah".

${ }^{38}$ Chiste análogo en un villancico atribuido a Sor Juana (Obras, ed. Méndez Planearte, t. 2, p. 342): las palabras que le dijo Cristo a San Pedro (Juan, 21:22), "Si eum volo manere, quid ad te? 'Tu me sequere", a muchos les parecieron duras; "pues esas mismas palabras / a él le sonaron a papa" (él entendió: 'Tú serás mi vicario, tú serás el primer papa').

${ }^{39}$ Análogo tono de jáçara en Sor Juana, t. 2, pp. 10-12, donde la valentona es la Virgen María: "Allá va, fuera, que sale / la valiente de aventuras $[\ldots]$, / la de quien tiembla el infierno", tan enemiga del pecado, "que a puntapiés / no hay demonio que la sufra". Cf. también t. 2, pp. 68-69.

${ }^{40}$ Este ejemplar de Scholberg está ahora en la Biblioteca de El Colegio 
Apolo y el Coro de las Musas, pero el libro de Scholberg me abrió los ojos a lo que fue esa "alma en litigio", ese marrano escindido entre el cristianismo y el judaísmo. Muchos años después, en noviembre de 1990, conseguí una fotocopia de la Fábula, y entonces los dos intereses inconexos - la fábula burlesca y el escritor marrano- se juntaron e hicieron jclic! La lectura de la Fábula, sumada a una relectura de ScHOLBERG, me hizo ver que el autor no podía ser sino Miguel de Barrios. No tengo pruebas documentales, científicas, de que así sea. Simplemente estoy convencido de ello. Tampoco voy a armar una argumentación sistemática para probarlo. Mis argumentos, que no son pocos, irán esparcidos por las páginas que siguen, cada uno en el lugar que le toque. Si alguien llega a desmentirme, revelando el nombre del verdadero autor, o demostrando siquiera que Barrios no puede serlo, se lo aceptaré, por supuesto. Pero no creo que tal cosa suceda.

\section{La FábULa de Christo y la Magdalena}

Una cosa son las irreverencias juguetonas de un poeta cristiano como Jerónimo Cáncer y otra las irreverencias serias de un poeta anticristiano, por mucho que sea el parentesco lingüístico y estilístico entre unas y otras. Los poetas cristianos del Barroco, ha observado Dámaso Alonso, "muchas veces emiten ideas extravagantes dentro de lo religioso, y aun heréticas, como si lo que quisieran fuera darle un susto al oyente; pero un golpe de timón desvirtúa en seguida la barbaridad enunciada; y el devoto auditorio puede ya respirar (y reír de su propio susto)", 41 . Claro que ese "golpe de timón" no lo da necesariamente el poeta mismo: quien oía o leía que Santo Domingo de Guzmán "un domingo quebrantaba / muy sin cargo de conciencia', entendía muy bien lo que el travieso poeta quería insinuar: que, muy santo y todo, el héroe del cuento no sólo pecaba contra el mandamiento de "santificarás las fiestas", sino que ni siquiera se sentía culpable; pero él, el lector, sabía por su cuenta cuál era el sentido real:

de México. Todas las anotaciones que hay en él son mías, y no parece haber tenido otros lectores.

41 D. Alonso, "Un manuscrito sevillano de justas en honor a santos (de 1584 a 1600)", en sus Obras completas, t. 3, 1974, p. 107. Me viene al recuerdo lo que decía Chesterton de la paradoja: no es sino la verdad, pero puesta patas arriba para llamar la atención. 
Santo Domingo sometía su cuerpo a grandes mortificaciones, sin miramiento alguno.

Idealmente, el resultado era la edificación de los devotos: ¡a qué grado excelso llevó el santo la virtud de la penitencia! Los poetas anticristianos, en cambio, aspiran a la destrucción. Sus burlas son burlas sin vuelta de hoja, y cuando no llaman al pan pan sino que se andan con metáforas y alusiones, la tarea del lector u oyente es encontrar el peor sentido posible, la mofa más sangrienta, el máximo aplastamiento de las cosas que para la masa conservan todavía un valor "sagrado" 42 . Y nada más sagrado que los mitos que dan coherencia a una sociedad, es decir, las creencias religiosas, reacias siempre a toda crítica, protegidas siempre por un estamento sacerdotal y a menudo defendidas y reivindicadas literalmente a sangre y fuego. En estos tiempos nuestros es noticia mundial la condena que pesa sobre Salman Rushdie por haber "vilificado" a Mahoma. En 1894, en la católica Baviera, Oskar Panizza sufrió persecución policial, secuestro de libros y un año de cárcel a causa de su irreverente Liebeskon$z i l^{43}$. Y no son raros hoy esos "piquetes" de fanáticos para quienes la libertad de expresión sigue siendo idea de.inspiración diabólica y tratan de sabotear películas o piezas teatrales que trasladan los temas religiosos al nivel de la tierra o que ponen al

42 Para entender mejor el fenómeno, hay que darle a sagrado el campo semántico más amplio posible. El supuesto básico de la Batracomiomaquia era que todo el mundo conocía la Ilíada y la tenía por el más "sagrado" tesoro cultural de Grecia. Así también, el Virgile travesti (1648) de Scarron, el Ovide en belle humeur (1668) de Dassoucy, las Odes d'Horace en vers burlesques (1652) de Charles Beys (y, todavía a comienzos del siglo xx, el Horatius travestitus de Christian Morgenstern) suponen lectores criados en la "sagrada" tradición clásica - y que, a lo mejor, después de la lectura, van a concluir que la veneración de lo clásico tiene mucho de superstición-, tal como Alfred Jarry se dedicó gozosa y ferozmente a poner por los suelos la fama "sagrada" del lycée francés. Cuando Góngora escribió sus romances de Hero y Leandro y de Píramo y Tisbe, las historias de los infelices amantes eran "sagradas", aceptadas por la masa de lectores como cosa patética y admirable; y él pudo decir que justamente por eso había decidido burlarse. Para él, eso sagrado tenía la significación de 'pedestre', 'vulgar', 'choteado'.

${ }^{43}$ Manejo la traducción de Josep Elias, El concilio de los dioses, en la ed. de México, 1978 (col. La nave de los locos). En el prólogo dice André Breton que, durante el juicio que se le siguió en Munich, de nada le valió a Panizza aducir "ejemplos anteriores" de irreverencia: quedó convicto de "haber utilizado muchos más recursos y haber llegado más allá que sus predecesores" (p. 10). Me gustaría saber a qué predecesores alude Breton. Sólo me viene a la cabeza el caso de la Guerre des dieux (1799) del gran libertino Évariste Parny. 
descubierto la actitud del papa Pío XII frente a Hitler y el nazismo $^{44}$.

En España, donde las irreverencias juguetonas eran no ya toleradas sino aplaudidas, y aun muy aplaudidas, hubiera sido inimaginable una irreverencia seria, algo que calara hondo. Refiriéndose a la Fábula cuyo texto se verá en seguida, decía Miguel Herrero que es "la pieza más chocarrera e irrespetuosa de aquella católica edad" 45 , lo cual está bien dicho, pero necesita aclaración, para que no se entienda que en España, en la inquisitorial España del siglo Xvir, hubo quien escribiera una cosa así. Ciertamente, lo que hace Quevedo en el soneto "Llegó a los pies de Cristo Madalena..." es sacar partido cómico (pulla contra los boticarios) del episodio evangélico del ungüento de nardos, y, aunque los cuartetos y el primer terceto parezcan "serios", el conjunto es burlesco ${ }^{46}$. Pero tomar totalmente en chunga a Santa María Magdalena hubiera sido suicida. En cambio Miguel de Barrios, al añadir a sus fábulas la de Cristo y la Magdalena (tan "mitológica" para él, tan mentirosa, como la de Dafne y Apolo $)^{47}$, no corría ningún peligro. Su Magdalena está escrita

${ }^{44}$ Hay también, claro, el escándalo que no se traduce en medidas inquisitoriales graves. De mis apuntes sobre esto - que, la verdad, son muy exiguos - tomo un caso: la reseña que publicó Robert KemP en Les Nouvelles Littéraires, 18 de julio de 1957, sobre el recién aparecido Joumal intime d'Hercu$l e$, de A. Dubois La Charte; Kemp se declara enemigo de esa clase de parodias; de niño cayó en sus manos 'l'atroce Bible comique de Léo Taxil, et ses ignobles gravures. Je ne comprenais rien. Mais le coeur me levait. Je l'ai fait brûler". (Yo le habría dicho a Kemp que mejor me cediera su ejemplar.)

${ }^{45}$ M. Herrero García, Estimaciones literarias del siglo xvii, Madrid, 1930, p. 364 .

${ }^{46}$ Blecua pone este soneto entre los "poemas religiosos", pero Astrana, con toda razón, entre las "sátiras varias".

${ }^{47}$ La Magdalena del cristianismo vulgar estaba ya "mitificada". No hay en los evangelios base alguna para ver en ella una "pecadora arrepentida", como dicen, entre otros infinitos, Quevedo en el soneto mencionado y fray Luis de León en la oda "Elisa, ya el preciado..." (donde la Magdalena, antes de cambiar los amores humanos por el divino, estaba "perdidamente dañada"). Es verdad que Jesús había expulsado de ella "siete demonios" (Lucas, 8:2), pero el evangelista pone este caso junto con el de otras "mujeres que habían sido curadas de malos espíritus y de enfermedades". La Magdalena que aparece en una de las primeras escenas del King of Kings de Cecil B. DeMille como cortesana, como hetaira de lujo, es una creación folklórica. Creación seguramente natural, y aun necesaria: a Jesús, como a Adán, "le hacía falta una mujer". Es notable la naturalidad (y el respeto) con que José Saramago, en su Evangelho segundo Jesus Cristo, hace a Jesús y María Magdalena amantes estables. Pero las tradiciones folklóricas suelen ser irrespetuosas. 
para regocijo de correligionarios y cómplices. Bien pudo haberla leído en la academia de los Sitibundos o en la de los Floridos, donde tan activo estuvo (supra, p. 415), tal como muchas fábulas mitológicas burlescas fueron pasatiempos académicos. Además, es evidente que esa Magdalena no estaba destinada a las prensas. Era impublicable ${ }^{48}$.

El texto que publico se basa en el manuscrito 17.687 de la Biblioteca Nacional de Madrid. Hay un segundo manuscrito, que es el que conoció J. A. van Praag, y que se encontraba, según dice en su citado artículo de 1954, p. 295, en "la Biblioteca del Seminario Sefardí en Amsterdam". He tratado de conseguir fotocopia de él, pero mis gestiones han sido en vano ${ }^{49}$. Lo lamento,

Hace muchos años, en una reunión de amigos, un conocedor del folklore lírico de México, al cantar la canción "El Venadito", soltó de pronto una copla que nadie conocía: "Santa María Magdalena / era una mujer muy lista: / en la noche de la Cena / se . . . a San Juan Bautista...", pero dejó manco este verso y no se atrevió a cantar los versos 5 y 6 . Todavía en 1959 o 1960 el mexicano José Natividad Rosales escribía (según una reseñita anónima de la Rev. Mex. de Literatura, febr.-marzo de 1960, p. 57) un libro intitulado Los amores de Cristo, donde por supuesto figura la Magdalena (que también figura, aunque fugazmente, en el Liebeskonzil de Panizza). - En cuanto a los poemas "serios", está desde luego el monumental libro de Malón de Chaide; está la Vida de la gloriosa Magdalena, en octavas, de incierto autor, incluida en el Thesoro de divina poesía recopilado por Esteban de Villalobos (Toledo, 1587, y Madrid, 1604); está el cuarto de los "llantos" en que se divide el Valle de lágrimas de Cristóbal de Mesa (1604); están Las lágrimas de la Madalena de Lope de Vega, sarta de 100 octavas (en sus Rimas sacras, 1617). Pero es dudoso que Barrios haya leído esas cosas.

${ }^{48} \mathrm{~K}$. BRown, "Gabriel de Corral: sus contertulios y un manuscrito poético de academia inédito", Castilla, Universidad de Valladolid, 1982, núm. 4, pp. 9-56, publica las composiciones que se leyeron en una sesión académica "para hombres solos", y que son muy obscenas. Así también la Magdalena se escribió "para judíos solos".

${ }^{49}$ El Dr. Dick A. Papousek, director de la Facultad de Letras de la Universidad de Groningen, tuvo la gentileza de informarme que la biblioteca del Portugees Israëlitische Seminarium Ets Haim, de Amsterdam (rival de la Bibliotheca Rozenthaliana en cuanto a fondos judaicos), "actualmente se encuentra prestada para siempre en Jerusalén". Escribí entonces a la dirección que me dio el Dr. Papousek (Jewish National University Library, P. O. Box 503, Jerusalén), indicando la signatura que el manuscrito tenía en el catálogo de la Biblioteca Ets Haim: HS-EH-48 B 7 (dato proporcionado asimismo por el Dr. Papousek). Pero de la Jewish National University Library me respondieron que allí no tenían el tal manuscrito, y me aconsejaron acudir "a la Biblioteca Nacional de Madrid" (!). - En el ms. Ets Haim, según la descripción de van Praag, la Magdalena es parte de un conjunto que lleva como título 
pero no mucho, pues el texto del manuscrito madrileño es sumamente satisfactorio, y tiene todas las trazas de ser copia directa del original. (Por lo demás, la letra es clara, y casi no tiene abreviaturas.)

Los retoques que he hecho son mínimos. Hay en el poema tres versos hipométricos $(230,280,325)$ y seis hipermétricos $(162,163,342,359,422,565$; no cuento el v. 29, porque la sinéresis poe-ta no es rara). Después de madura reflexión decidí hacerles una pequeña operación de cirugía plástica, primero porque, aunque algunos de ellos puedan ser del autor ${ }^{50}$, otros son fácilmente atribuibles a descuido del copista, y segundo porque no tiene mucho sentido dejar esa clase de guijarros en el camino de la lectura. Claro que en todos los casos queda explicación en la nota respectiva. (Sólo he dejado intacto el v. 283: véase la nota.)

Por la misma razón - quitar guijarros del camino- he corregido, sin decirlo en nota, cosas como uzar, acazo, Muza, dezengaño, pizar y camiza, o como salvarce y conciderar, o como siencia, dulse y cavallerissa. Baste recordar que Barrios era andaluz (véase la nota al v. 8).

El copista del ms. de la B.N.M. era seguramente de origen portugués. La comunidad marrana de Amsterdam estaba formada por españoles y portugueses ( $y$, según entiendo, los segundos eran más que los primeros). De los personajes que menciona Scholberg -incluyendo los miembros de las academias de los Sitibundos y de los Floridos-, muchos llevan apellido portugués. Ahora bien, hacía dos siglos que los portugueses estaban familiarizados con la lengua española: leían mucho y escribían mucho en castellano. Es natural que fuera ésta la lingua franca, la lengua en que se comunicaban unos con otros. Pero toda lingua franca supone injertos y transfusiones. Ejemplo de esto son, en el

general "Relación de la Inquisición y de lo que padeció en ella Antonio de Fonseca, con dos más historias, una de Xpto y de la Magdalena y una del famoso don Sabatay Seby, anno 1583", y "consta de 56 páginas en cuarto". Según el Dr. Papousek, la Magdalena ocupa "15 páginas, de las cuales 4 están en blanco", o sea que son sólo 11 "páginas". Pero sospecho que se trata de folios, no de páginas. (La copia del ms. madrileño ocupa 11 folios.)

${ }^{50}$ Barrios comete errores de métrica: véase por ejemplo ScHOLberG, p. 57 (verso 7 del soneto) y p. 188 (verso 5 de la $11^{\text {a }}$ octava). No cuento casos como "y al Kahal Kadós que por piedad sagrada" (p. 128) y "llamóse Bahal Zephón, que se interpreta"' (p. 162), pues es claro que Barrios pronunciaba kal, bal, y no kajal, bajal. En fin, por lo menos algunos de los errores métricos de la Magdalena pueden ser originales de Barrios. 
manuscrito madrileño, formas como coitado, coaderno y fráugoa 'fragua', o como intendimiento, erritado y Cupedillo, que muestran unos deslizamientos $\alpha / u$ y $e / i$ más frecuentes en portugués que en castellano. (Los Enigmas de Sor Juana Inés de la Cruz, cuya edición estoy preparando, se conservan en manuscritos hechos por copistas portugueses, y ahí se leen cosas como divirtir, inigmas, solecita, deficultosa y homecida.)

Dos portuguesismos merecen atención: el nariz y los narizes (vv. 179 y 181) y creere 'creyere' (v. 577). El masculino de nariz podría tener una pequeñita justificación (véase la nota respectiva), pero no así el bisílabo creere. Estos portuguesismos no formales, sino estructurales, podrían inducir a pensar que el autor de la Magdalena no fue Barrios, sino un judío portugués. A esta dificultad respondo, en primer lugar, que se trata de dos casos aislados en un poema muy largo; en segundo lugar, que bien pueden explicarse como aportuguesamiento de Barrios, dado el medio lingüístico en que vivía; y en tercer lugar, que difícilmente dominaría un portugués todo ese cúmulo de réfrancillos y dichos, tan idiomáticos — "echar el bofe", "echar la soga tras el caldero", "poner pies en polvorosa", "estar el pandero en buenas manos", etc., etc. - que constituyen una de las gracias de la Magdalena.

De estos dichos y refranes no anoto sino los que siento menos comunes, para ahorrarle trabajo al lector. (Los versos o vocablos con asterisco son los que llevan anotación al pie de la página.)

Una última advertencia. A mediados de 1991 supe, por carta de un amigo, que el profesor José Lara Garrido, de la Universidad de Málaga, estaba interesado en la Fábula de Cristo y la Magdalena. Le escribí no una, sino tres veces, proponiéndole que la editáramos entre los dos — con lo cual me habría sentido muy honrado-, pero nunca obtuve respuesta ${ }^{51}$.

${ }^{51}$ Me consta que LaRa GarRido ha explorado, y muy bien, no pocas zonas de la poesía del siglo XVII, y en mis apuntes tengo la noticia de un artículo suyo, "Consideraciones sobre la fábula burlesca en la poesía barroca. (A propósito de una versión inédita de la de Apolo y Dafne)", publicado en una revista que no he podido localizar: Revista de Investigación (Fil.), VII, 1983. 
Fábula de Christo y la Magdalena compuesta por frai Antonio Márquez, catedrático de Visperas en la Universidad. de Salamanca, que estando en la Inquisición escrivió este discurso

en Londres en 45 de enero del año que viene de 1003 y $3 / 4^{*}$

\section{Cantar de Christo la funesta historia} sin más ni más me vino a la memoria*. $\mathrm{Mi}$ voz escuche todo el orbe entero, que su vida y milagros cantar quiero. Allá en el tiempo de Mari Castaña, con ignorancia estraña, se usava como trajes muchos dioses, y la rueda del Tiempo, dando coces*, abrió el portigo a nuestro entendimiento

Título. Está en un folio sin numerar ( $\mathrm{v}^{\circ}$ en blanco), y su letra no es la de quien copió la Fábula. En el ms. Ets Haim, según lo ha descrito van Praag, este título presenta dos diferencias: a) en vez de "que estando en la Inquisición...", etc., se lee "que haviendo padesido grandes tormentos en la Inquisizión, escrivió este discurso en Londres"; desaparece así la incongruencia " "estando en la Inquisición escrivió en Londres" (aunque quizá la incongruencia esté puesta adrede); b) en vez de la chistosa fecha "en 45 de enero del año que viene de 1003 y 3/4", se lee escuetamente "en el año de 1623". Por supuesto, también este año es ficticio - baste recordar que la Dafne de Polo de Medina se publicó en 1634-, tal como es ficticio el año 1583 que se atribuye a la "historia del famoso don Sabatay Seby" (supra, nota 49), pues Sabbatái Zeví (sobre el cual véase supra, p. 413) nació en 1626 y murió en 1676.

2. Esta presentación del poema como impromptu fue invento de Polo de Medina, que comienza así su Dafne: "Cantar de Apolo y Dafne los amores / sin más ni más me vino al pensamiento" (Barrios repite después, v. 31: “de súpito me vino al pensamiento..."). Otras imitaciones: "iVálgame Dios, qué es esto que me ha dado, / que a versos en mis cascos ha tocado!" (José Téllez, Fábula de Júpiter y Europa); "Hablando con perdón, yo tengo gana / (vergonçoso lo digo) de hazer versos" (Antonio de Solís, Hermafrodito y Sálmacis); "El pintar de Lisarda la belleza / en que a sí se excedió Naturaleza / con un estilo llano / se me viene a la pluma y a la mano" (Sor Juana, Retrato de Lisarda). Un anónimo del siglo XVIII (apud Cossío, p. 790) comienza su Historia, fábula o cuento de Cibeles, Atis y Sangarita citando a Polo, a Solís y a Sor Juana: "Sin más ni más le vino al pensamiento / cantar de Apolo y Dafne los amores / al murciano Jacinto; / a la Musa del indio firmamento / se le vino a la pluma dar colores / de Lisarda al recinto [...]; / otro de Hermafrodito $[\ldots]$ / hizo una silva porque tuvo gana...".

8. Rima "andaluza", dioses/coces. Y véase infra, 127 cavalleriza/prisa, y 369 empresa/cabeza. Rimas así se encuentran en otras obras de Barrios, como en La Verdad, v. 2964 (reza/mesa). 
10 para reconocer su vano intento.

Aora anda muy cabido

un Dios, de muchos sabios aplaudido;

mas el Tiempo, maestro

que nos da desengaños, sabio y diestro,

15 al mundo mostrará su culto ciego*.

$Y$, pues ha de ser fábula, sea luego,

que es grande ofensa y es agravio visto

no meter en el bayle a Jesuchristo,

y es necessario, siendo tan sublime,

20 que como al mismo Júpiter se estime.

Su fábula no hazer es darle como,

porque Christo es un Dios de tomo y lomo*.

¡Que no hagan caso dél mucho me admira!

¿Son acaso los otros más mentira?

25 Pero como le soy aficionado, su fábula he de hazerle de contado, porque muy grande ingratitud parece

no tratar de este Dios como él merece.

Estando, como poeta pensativo,

30 con muerto aspecto y con ingenio vivo, de súpito me vino al pensamiento contar aora un celebrado cuento tan verdadero, que no admite errores: así lo afirman doze Pescadores

35 que, por lograr de Christo las mercedes, largaron barcos y dexaron redes;

y pues que ya le alaban

quantos aran y cavan, yo para mí con certidumbre advierto

40 que como el Evangelio es esto cierto.

Señora Musa, su favor no invoco, ni que me supla usted mucho ni poco, que para escrevir versos tan ruïnes pido me suplan veinte mil malsines*;

15. Seguramente los vv. 5-15 han de entenderse así: 'El antiguo paganismo, religión vana, ha dejado de existir; también pasará de moda esa otra religión vana, el cristianismo, por muchos secuaces que hoy tenga'. Véase infra, p. 451.

22. O sea: no hacer esta Fábula sería "ningunear" a Cristo, ofenderlo: dar como es 'dar chasco, zumba o cantaleta" (Dicc. Aut.). " ¿Vive Chipre, que trata de dar comos!", dice un verso de la Dafne de Polo. Y cf. en seguida los vv. 27-28.

44. Los malsines (palabra que viene del hebreo) eran los que delataban a 
45 que si de hazerlo su merced se escusa, yo no puedo escrevir versos sin Musa*, y así, aunque sean perversos, para no gastar prosa escrivo versos.

Érase una muger de buena vida,

50 de todos adorada y aplaudida, que aun al más alentado por su dinero daba su recado. Fue un pobre carpintero su marido, tan llano, tan afable, tan sufrido,

55 que viendo su muger en compañía, no dixo nunca Aquesta boca es mía*. Deste modo logró las ocasiones, y corriendo de amor las estaciones, sin dezir Agua va, muy entonada,

60 quando la niña se mostró preñada y se le entró (no sé cómo lo diga) el demonio de un Dios en la barriga; y fue muy admirado que al darse un verde le salió encarnado*.

65 Estimando el muchacho que tenía el buen Joseph con mucha cortesía,

los judíos ante la Inquisición, o sea lo peor de lo peor. La "siniestra figura" del malsin, dice OELMan, p. 186, aparece con frecuencia en la poesía de Enríquez Gómez.

46. Cf. Polo, Dafne: "Aquí es obligación, señora Musa, / si ya lo que se usa no se excusa...". Lo que dice Barrios no es muy claro: nos quedamos sin saber si prescinde o no de la Musa; sería más lógico si el v. 46 dijera "yo bien puedo escrivir versos sin Musa".

56. Desde el punto de vista cristiano, el silencio de San José al ver preñada a la virgen María es su rasgo más "heroico". En el cuarto de los Villancicos a San José (1690) Sor Juana compara, con muchas agudezas, la mudez de Zacarías (que fue "pena") con el silencio de San José (que fue "industria"). Barrios presenta al esposo de María como el clásico marido paciente ("Dios me lo guarde a mi Diego Moreno, / que nunca me dijo ni malo ni bueno"). Pero también en el folklore cristiano suele ser San José figura cómica. - En La Verdad hace Barrios un chiste parecido (v. 810): un padre alcahuete anda ofreciendo a todos la belleza de su hija (es Dios, que quiere que todos tengan amor a su Ley).

64. Darse un verde es 'holgarse en vanquetes y placeres' (CovarRubias). El salió encarnado alude naturalmente a la Encarnación. En el octavo de los Villancicos a San José dice Sor Juana: "Érase un buen carpintero, / de esos que labran en blanco [...]; / nunca gustó de colores, / por lo que tienen de engaños"; y sin embargo en su taller había un "Sagrario [María] / con un Niño 
que como es bien nacido, se muestra a quien le hizo agradecido, pues sin trabajos ni passar dolores

70 le daba un hijo allí como unas flores*. Mas muchos dizen que su madre bella aun después de parir quedó donzella.

Pero quien tal dixere o tal diría, cuénteselo a su tía;

75 que, según lo imagino, obra fue de un herrero su vezino, pues eran, según tengo imaginado, María blanca, y Joseph cornado*. ¡Oh Musa maldiziente,

80 detente, que ese Niño es mi pariente! $\mathrm{Y}$ porque assí te quadre, muy bien pudo nacer hijo sin padre, pues de Venus escriven varias plumas que del mar la parieron las espumas.

$85 \mathrm{Y}$ por que sepas quánta ciencia cobras, sería el Niño hijo de sus obras.

Con ocioso descanso y grande espacio Jesús pisava el celestial palacio, surcando ayroso, con ardientes huellas,

90 ondas de resplandor en mar de estrellas; mas su Padre, mirando con cuidado (que el ciego Cupidillo es mui mirado) que tenía ya edad el tal mozuelo, y que nunca en el cielo

95 ganó tan solamente la comida, "Vaya a buscar su vida -le dixo- y salga de la ethérea casa,

que no tuvo / igual, de bien encarnado". En las quintillas mencionadas infra, p. 449, Jerónimo Cáncer le dice al Niño nacido en el pesebre: “¡Ah buen Dios enamorado, / Vos por el hombre encarnado, / Vos por el hombre pajizo!"

70. Cf. Sor Juana, soneto "Aunque eres, Teresilla, tan muchacha...", terceto final: cuando el pobre Camacho barrunta algo, Teresilla le da a entender que ha hecho "de ajena siembra, suya la cosecha". Así aquí el "cortés" carpintero le está " agradecido" a quien se tomó el trabajo de sustituirlo en la tarea de hacer un hijo. (El gerundio del v. 65 está muy en el aire. Dan ganas de corregir: "Estimaba..."; o sea: el buen José veía con buenos ojos a ese muchacho.)

78. El chiste de las monedas (blancalcornado) había sido bastante explotado. Cf. Quevedo, letrilla "Con su pan se lo coma": "Que case con bendición / la blanca con el cornado...". 
por que sepa del pan que el Diablo amassa;

corra el mundo aunque muerda en una piedra,

100 por quanto entre los suyos nadie medra;

y así mire que el Diablo no le engañe,

que sólo quien las sabe es quien las tañe;

abra el ajo, no sea majadero;

sepa que en buena mano está el pandero.

105 No ha de ocuparme más estos balcones, aunque vaya a morir entre ladrones.

$\mathrm{Ya}$ en un cofre le puse sus camisas.

Vaya, que allá se lo dirán de missas por si le ahorcan, en el mundo entero

110 la soga quiere echar tras el caldero*.

El cielo es tierra donde no se gana:

aquí no ha de quedarme hasta mañana".

El Niño replicó: "No se alborote,

que no pretendo hazerme Don Quixote

115 vengando agenos duelos;

yo estoy bien en los cielos,

que me viene muy ancho.

Sea usted Don Quixote y yo Don Sancho*, que soy hombre sufrido".

120 Llegáronle al oýdo

las razones ferozes,

quando Cupido, disparando coces,

desde el ethéreo velo

dio con él en el suelo,

125 y se metió, quando veloz corría,

en el vientre espacioso de María.

En la cavalleriza

le vomitó su Madre, tan de prisa,

que, por que al mundo asombre

130 con su verbo, Jesús le dio por nombre*.

110. No sé cómo empalmar este verso con el anterior. Quizá haya que leer " $y$ en el mundo entero" ("por si le ahorcan, y por si [en ese caso] quiere echar la soga tras el caldero").

118. Herrero García, Estimaciones literarias, op. cit., pp. 364-365, transcribe los vv. 91-118 entre otras menciones del Quijote en la poesía del siglo XVII. - En unas quintillas contra Juan de Prado, judío ateo y epicúreo que había sido expulsado del Mahamad de Amsterdam, Barrios lo llama "Don Quixote en Rozinante, / y en el comer, Sancho Pança" (véase mi "Fortuna varia", p. 496).

130. O sea: este Niño, destinado a causar asombro, se llamó Jesús por 
Quando estava en el mundo, en puerto tan inmundo, tres Reyes vienen con ligera huella siguiendo el norte de su clara estrella,

135 y llegando a su esphera, con tres Reyes se vio puesto a primera*; mas con terribles modos como a unos negros los trató a todos.

(Referir su pintura es escusado,

140 porque yo no le puedo ver pintado, y ya hay tanto pinzel de su hermosura, que no puede hazer falta mi pintura.)*

Con amorosa pena el bofe echava por la Magdalena,

145 porque era, con beldad y con decoro, la bella nimpha como un pino de oro. El pintar sus matizes es mui justo, por que sepan que tuvo lindo gusto, siendo de rostro hermosa primavera,

150 sin quitar ni poner, desta manera: Era su pie tan dulce maravilla, que como redondilla calzava quatro sílabas tan breve, dexando que era nieve;

155 por modo más diverso digo que era su planta pie de verso; mas tan ligera corre por el prado, que no me pareció de pie quebrado*.

el grito de "asombro", „Jesús! (o quizá ¡Josú!), que dio su madre al parirlo $\tan$ de prisa. (Barrios emplea vomitar 'parir' tal como Sor Juana, en el citado soneto, emplea desembuchar, que es más "fuerte".)

136. Primera es "juego de naipes bien conocido", y ponerse a primera es "ponerse a ventura' (Covarrubias). Supongo que el jugador que tenía tres Reyes bien podía prometerse el triunfo. Véase también adelante, vv. 344-346.

142. Fue Góngora, sobre todo con su Píramo y Tisbe ("La ciudad de Babilonia..."), quien introdujo la costumbre de "retratar" a los personajes de una fábula. Lo normal es que vaya primero el retrato de la heroína; Barrios altera el orden, pero sólo para desentenderse rápidamente de la obligación de retratar al héroe.

158. El pie de la hermosa Magdalena es tan breve como un pie quebrado, o sea de sólo cuatro sílabas; pero antes (v. 153) se han atribuido estas cuatro sílabas al pie de redondilla, que es de ocho. En los ocho versos dedicados al pie hay los elementos para una agudeza, pero ésta está mal articulada. 
Parecían los ojos, por rasgados,

160 pobres poetas, míseros soldados, pues* eran tan flecheros

(dexo por claro* el nombre de luzeros), que $\mathrm{p}\left[\right.$ or ${ }^{*}$ que el orbe todo se despache, valientes tiran rayos de azabache.

165 Las cejas, medias lunas de su cielo, el pintar sus matizes viene a pelo:

dos líneas de azabache son, tan bellas, que Amor las puso sobre las estrellas, y en cándido papel de rostro franco

170 son dos firmas en blanco, con que Amor cauteloso

obliga [a] amar su rostro siempre hermoso.

Por el nevado cuello ten[d]ía* rayo a rayo su cabello.

175 Si a dezir su medida me acomodo, sería su cabello deste modo, y a nadie cause espanto, porque aun era más largo más de tanto. Era el nariz* perfeto.

180 ( $i$ Vistes, lector discreto, en dama alguna los narizes buenos?

Pues éste lo es assí, ni más ni menos.)

La boca yo no sé si la tenía, porque sólo al pedir se conocía

185 que era aquesta boca tan risueña, mas tenía la falta ser pequeña.

Y pues de su beldad lo sabes todo*,

161. Este pues está al margen, en sustitución de una palabra tachada que parece ser pero (lo cual hace mejor sentido: "ojos rasgados, pero buenos flecheros").

162. El ms. dice claros, lo cual hace hipermétrico el verso.

163. Otro verso hipermétrico: dice para en vez de por.

174. El ms. dice tenía; pero la cabellera se tiende (no se tiene) por el cuello.

179. Sólo en Nebrija ha encontrado Corominas "el uso de nariz como masculino" (Barrios era andaluz, como Nebrija). Añádase Cristóbal Colón, Diario, 12 de octubre de 1492: los indios encontrados en Guanahaní se pintan de varios colores, unos la cara, otros todo el cuerpo, otros sólo los ojos, otros "sólo el nariz". En otro lugar (v. 506) dice Barrios la nariz.

187. En realidad, no. Los "retratos" poéticos de la era barroca, que canónicamente empiezan en el cabello y acaban en el pie, suelen hacernos saber todo acerca de la belleza de la dama, presentándonos uno a uno sus ele- 
190 y así se lamentava

passo adelante y digo deste modo:

En el lecho Jesús no descansava, quando en líneas de luz de claro coche comenta el sol la gongorisma noche -que en sus obscuridades me parecen las noches Soledades-

$195 \mathrm{y}$, cruzando una vez el campo ameno, vio reluzir su rostro tan sereno por la nube de un manto* que venía más grave que otro tanto; y viendo la ocasión, con desenfado

200 de pe a pa le dixo su cuidado sin dimes ni diretes, por escusar terceros y villetes: "Mi reyna - dixo-, sepa que la adoro, y aunque soy buen judío en ella moro.

205 A padecer del cielo me he venido; y pues ya su desdén he padecido, trate usted de adorarme. ¿Con quién hablo? No guste de enfadarme*, que juro a Christo, con mi boca sucia,

210 que buscando una astucia, si acaso no me quiere..., hará vuestra merced lo que quisiere".

Con la oreja de un palmo le escuchava, $y$, aunque dello gustava,

215 sin oýr otra cosa

mentos visibles (y a veces hasta los "invisibles"): dicen cosas no ya sobre la boca en general, sino sobre uno y otro labio, sobre los dientes, sobre el aliento. Barrios nos escamotea, entre otras cosas, los brazos, las manos, los pechos y la cintura. Una de las ocurrencias de Polo de Medina fue invertir el orden: expresamente nos advierte que le ha dado la real gana de empezar su retrato de Dafne "por los talones". También Barrios comienza con los pies, pero los elementos que siguen no están puestos metódicamente. En cambio, su autorretrato burlesco "Por obedecerte, Clori...". (a juzgar por el fragmento que reproduce Oflman, p. 201) sí es canónico: frente, cejas, ojos, narices.

197. Como quien ve el rostro sereno de la luna a través de una nube ligera, así Jesús ve el rostro de la Magdalena a través del manto que lleva. (Eran famosos los mantos de humo, de seda negra y transparentes.)

208. En la Fábula de Dafne dice Apolo: "Usted me ha de querer, cuadre o no cuadre [...]. / Diga, ¿empieza a quererme? ¿Con quién hablo?" 
al punto puso pies en polvorosa*;

puso la jira* y le mostró la cola, haldas en cinta, y escurrió la bola; pues tanto, en fin, volava,

220 que iva la nimpha que se las pelava.

Quando el amante ciego

vio que tomava las de Villadiego

dexando a buenas noches su esperanza,

tras ella parte y muy veloz la alcanza,

225 porque era un Dios de ingenio tan profundo, que alcanzó todo quanto vio en el mundo.

"Sepa - la dixo-, pues es tan discreta

(aquí la puso el cabe de paleta)*, que con ella he de verme en blanco lecho,

230 porque [yo] soy un Dios de pelo en pecho.

Siendo usted claro sol, era indecencia

el dexarme a la luna de Valencia;

y aunque se muestre del favor avara, jamás me ha de mirar de mala cara,

235 pues tan linda la tiene;

la tempestad de su rigor serene

ofreciéndome el alma por despojos;

bien sé yo que me muestra buenos ojos

lanzando negros rayos por tributo,

240 que por matar de amor se visten luto.

¡Ea, despache! Quiérame mil vezes,

porque la daré un pan como unas nuezes:

tómelo sin tener desto embarazo,

216. Tal vez para fingir pudor (luego la vamos a ver muy desvergonzada). O tal vez simplemente porque era irresistible el recuerdo de la Dafne de Polo de Medina, que también "puso pies en polvorosa".

217. El sentido de jira (el ms. dice gira) parece ser aquí 'exhibición de manjares apetitosos'.

228. El sentido parece ser 'la puso entre la espada y la pared'. El cabe de paleta, en el juego de la argolla, es la menor distancia posible entre bola y bola, de tal manera que "errarle es de ruines jugadores" (Covarrubias). He aquí otras menciones: la frente de Dafne tiene "sus ciertos humillos de azucena. / Dixe azucena. En fin, no pude menos; / que el concepto me vino de a paleta" (Polo de Medina); "En conclusión, era Pan / (perdónenme aquí los cabes) / un dios de a paleta, y era / un dios tilde engerto en nadie" (Alejandro de Benavente y Quiñones, Pan y Luna); "Érase [...] / Acrisio, un rey de assí assí, / si no un rey de medio talle [...]. / Este, pues, rey de a paleta (y perdónenme lo cabe) / una hija tuvo..." (Melchior Zapata, Júpiter y Dánae). 
porque bueno es un pan con un pedazo".

245 "Yo soy - responde - una muger de chapa, $y$, pues me ve tan guapa, aunque más amoroso me requiebre, no ha de venderme a mí gato por liebre. Si de bolsa está flaco,

250 no pretendo comprarle gato en saco, porque son solamente mis amantes los que leyendo en tomos se hacen dantes*. $\mathrm{Si}$ de mi cuerpo quiere ser querido, pague un cuaderno haziéndome un vestido;

255 si persuadirme a sus amores trata, al discurso ha de abrir llave de plata, y después, si es discreto, cierre con llave de oro su conceto; porque yo, en mis sermones,

260 más que el lenguaje premio las acciones; que estimo en cosas tales más que metal de voz, voz de metales. ¡Cómo! ¿Sin tener coche me pretende gozar a trochemoche?

265 Todo me causa enfado no hablando el dinerillo de contado; pero si no le tiene, ni aun alhajas, por ser tan pobre que nació en las pajas, mal le daré de mi beldad la palma,

270 pues, con ser su merced Juan de Buen Alma, tiene mal cuerpo para que le quiera"'.

Christo, que vio tan linda bachillera, le dixo: "Si por coche lo haze sólo, mi amigo es en el cielo el dios Apolo,

275 que trae coche en el círculo estrellado y puede ser le quiera dar prestado; y si faltan cavallos, usted los tiene, pues que sabe echallos"**.

¿Quién tal dixo? Se dava a mil demonios.

280 "¿A mí se [me] levantan testimonios?" Parece la picavan mil avispas;

278. Seguramente caballos en el sentido de 'bubones', 'tumores venéreos'. 
por la fragua del pecho echava chispas*:

"Aunque me ve hermosa y bella*, mucho más que su madre soy donzella;

285 y pues del cielo vino a este terreno, no le invḯ su padre acá por bueno".

Oyendo tan satírico bocablo estava Christo que se dava al diablo, y por vengar su agravio en este duelo,

290 patas arriba la tendió en el suelo.

$\mathrm{Si}$ salió del suceso bien parado

no lo tengo provado;

sólo sé que, purgando sus humores, tomó zarza en el huerto con sudores*,

295 y el matarle judíos no fue nada, que él ya traía la salud quebrada.

La dicha Magdalena, después desso, le dixo: "Sepa que la armé con queso. Es un grande jumento,

300 porque soy más probada que argumento*. ¿Piensa que me ha engañado, quando yo con mi humor se la he pegado?

Nadie de mí se escapa, porque doy al primer tapón zurrapa.

305 ¡Oh, qué linda quimera!

Si no me ruega, yo le persiguiera.

$\mathrm{Y}$ conozca en mis modos que he sido siempre libro para todos*;

282. " ¿Afuera, que arrojo chispas, / hecho una fragua, un volcán...!", dice el Apetito en La Verdad, v. 3323.

283. Este anómalo octosíabo podría convertirse fácilmente en heptasíabo ("Aunque me ve tan bella") o en endecasílabo ("Aunque me ve que soy hermosa y bella"), pero lo dejo tal cual.

294. Se creía que se "purgaban" los humores del mal de bubas (sífilis) tomando sudores (cf. Quevedo, "Tomando estaba sudores / Marica en el hospital..." ). La zarza es seguramente la zarzaparrilla, planta sudorífica y depurativa. A causa de esta enfermedad se dirá luego, v. 296, que Jesús "ya traía la salud quebrada"; y en los vv. 301-304 añadirá el poeta otros chistes sobre el contagio venéreo.

300. Cf. Quevedo, letrilla "Santo silencio profeso...": "Que trague el otro jumento / por doncella una sirena / más catada que colmena, / más probada que argumento...". todos.

308. Alude, por supuesto, al libro de Pérez de Montalbán intitulado Para 
pues mi negocio, con gentil coraje,

310 a qualquier punta le sirvió de encaje. ¡Llégate, Christo, si eres de la carda! ¿A qué tu amor aguarda? Dando al Diablo dos higas hemos de hazer nosotros buenas migas.

315 ¡Vámonos desde luego a gozar nuestro amor a sangre y fuego!'

Después destos amores que aquí canto, de pícaro Jesús fue a dar en santo, y en estas boberías

320 no sé qué cosas dixo de Messías, y que de Adán el bárbaro delito venía a perdonar como infinito: con congoxas y penas dava por él la sangre de sus venas;

325 que de Dios y [de] hombre era un enxerto; que resucitaría estando muerto, y que él y otros eran tres y uno, y otras cositas refirió importuno. Mas los judíos, por no andar en cuentos,

330 le asentaron duzientos, con que el pobrete iba tan contento, que de pencas se hazía en el jumento*. Pero, mostrando ingenio peregrino, les habló deste modo en el camino:

335 "Bien sabéis que el profeta Isaías en mí os ofrece el redemptor Messías, pues pobre estoy y en asno cavalgado, con que se cumple lo profetizado*. $¿$ ¿uál es mejor en lance semejante:

340 una ley vieja o una ley flamante? En prisión religiosa recebid esta* fe por digna esposa.

332. La penca es el 'pedazo de cuero o vaqueta con que el verdugo azota al delincuente'; y hacerse de pencas es 'no consentir fácilmente en lo que se le pide, rehusar lo mismo que desea' (Dice. Aut.), o sea 'hacerse de la boca chiquita', 'hacerse de rogar'. En otras palabras: a Jesús le encanta que lo azoten.

338. Quien profetizó lo del Domingo de Ramos ("Decid a la hija de Sión: He aquí tu Rey viene a ti manso y sentado sobre una asna") no fue Isaías, sino Zacarías.

342. Corrijo el manuscrito, que dice aquesta. 
Mi embaxada se funda

en confirmar la vuestra y dar segunda;

345 que, si con atención se considera,

mi ley es flux que os quita la primera*.

En la ley que he de daros

podéis vosotros, sin pecar, hartaros

de toda la inmundicia. No estéis tercos,

350 que comeréis tocino como puercos.

Todo aquesto os licita

la fe que os traigo yo, y éssa os lo quita

de vuestra boca, y tal el caso anda,

que siendo ella la novia, es la que manda,

355 y vos constantes observáis sus fueros,

con ser muger que recebís en cueros*.

Si guardareis mi ley para in eterno,

os iréis derechitos al Infierno.

$\mathrm{Si}^{*}$ en ir al Cielo vuestro intento estriba,

360 es cosa que se haze cuesta arriba.

Y si fuereis, después de mil quebrantos,

estáis papando moscas como santos;

que es lindo desenfado

hazerse harina por quedar salvado* .

365 Yo vi en mil ocasiones

que se condenan hasta los bufones,

y se van al Infierno sin falencia

y se llevan la gracia con paciencia;

quanto más que salvarse es una empresa

370 que os cuesta un quebradero de cabeza,

346. Ir a flux o a primera es 'ir a la parte, entrar en compañía a pérdida y a ganancia' (Covarrubias). Aquí es claro que el flux le gana a la primera. También dar segunda, en el v. 344, debe de ser lance del juego de naipes. Y véase supra, nota al v. 136.

356. El éssa del v. 352 se refiere a la Ley de Moisés, que prohibe ("éssa os lo quita') lo que la ley cristiana hace lícito. 'No dejéis - les dice Jesús a los judíos- que una novia que os llega sin dote, en cueros, sea la que mande, la que imponga sus fueros'. Con los cueros alude Barrios a los pergaminos en que se copian los rollos de la Torah. Cf. La Verdad, v. 286: la Ley de Moisés, "con belleza tan desnuda / que a todos se muestra en cueros".

359. El ms. dice $Y$ si.

364. El mismo juego de palabras harina/salvado (la hostia de la comunión y la salvación) aparece en $L a$ Verdad, v. 136, donde el Apetito le dice a la Mentira, refiriéndose al Entendimiento: "Hazle harina, por que no / te haga salvado'. 
y así no es bien que tal os aconseje, por ser cosa que no la hará un hereje"'.

"Dexe - responden- presunciones vanas;

375 no se meta en dibuxos, déle al Diablo el rocín y las manzanas*;

dexe usted predicar a los cartuxos;

dos bledos se nos da de su concierto, que todo es predicar en el desierto*.

Si mártir murir quiere,

380 váyase [a] predicar donde quisiere;

reprehenda de los turcos la ignorancia,

porque quantos más moros más ganancia;

predique a los cristianos

que no adoren las obras de sus manos,

385 que aunque ve que le adoran los menguados, en la hostia le comen a bocados;

si a consagrarle en el altar se mueven, su misma sangre beven, publicando su error con eficacia.

390 Gane dineros, no dé ley de gracia, porque para nosotros, si repara,

a Dios le juro que aun de balde es cara*.

Y advierta que le hablamos como amigos".

Jesús echava por aquessos trigos.

395 "Esto repetiré duzientas vezes

—dixo, volviendo al cántaro las nuezes-:

han de ser tijeretas erre a erre.

¿He de estarme? No quieran que me emperre

$y$, aunque estoy en mis treze, lo eche a doze*.

374. Con la expresión rocín y manzanas "se da a entender la resolución en que se está de hacer alguna cosa, aunque sea a riesgo y pérdida" (Dice. Aut.).

378. Cf. La Verdad, v. 278, a propósito de la promulgación de la Ley de Moisés durante el Éxodo: "el pedricar a Israel / fue pedricar en desierto".

392. El juego de palabras entre lo comprado (o vendido) y lo gratuito ("de gracia") aparece también en un notable pasaje de la "Alabanza jocosa a la Ley" (ScholberG, p. 131): Israel "aclama / a la que compra con sangre / por no querer-la de gracia". O sea: en vez de coger lo que se le ofrece gratis, Israel prefiere algo tan caro, que se compra con sangre (alusión a los judíos que pierden la vida por negarse a aceptar esa que los cristianos llaman "Ley de Gracia"). Pero el chiste del v. 390 es un boomerang.

399. En la "Alabanza jocosa a la Ley" mete Barrios, en versos consecutivos, las mismas dos expresiones, echarlo todo a doce y estarse en sus trece. Es notable la crítica contenida en los vv. 395-399 de la Magdalena. Como replicando 
400 Ninguno, ¡voto a Christo!, me conoce, pues no saben que soy el escogido que del Cielo a la tierra me he venido a perdonaros, con desdichas hartas. Callen mis barbas y hablen estas cartas

405 que aquí traigo conmigo, que es todo el Evangelio fiel testigo que $\operatorname{arroja}(n)$ contra vuestras opiniones balas de tinta en pálidos cañones. $¿$ Con cinco panes y dos pecezillos

410 no di a comer a un mundo a dos carrillos, donde a tente bonete bebieron en espléndido banquete, y después, recogida, nos sobró la comida y la bebida?

415 ¿Y un hombre endemoniado en dos bocablos no eché con mil demonios a los diablos? ¿A un ciego que de ver tenía antojos, con ser necio, no.le hize abrir los ojos? $\mathrm{Y}$ otros milagros hize semejantes,

420 que callo por faltarme consonantes".

Los judíos entonces con gran prisa respondieron* cayéndose de risa: "¿Con milagros nos viene? ¡Está famoso! El muchacho parece milagroso.

425 ¡Alto! ¡Vaya un milagro con gran prisa, pues no hay más que dezir Compónte, missa!* No sea con nosotros tan estraño:

a la acusación de terquedad lanzada por los cristianos contra los judíos, Barrios acumula, a propósito de Jesús y sus prédicas, toda una serie de expresiones que indican justamente terquedad: repetir algo 200 veces, volver al cántaro las nueces ('tornar a tratar una cosa que ya estava determinada y difinida', CoVARrubias), tijeretas (Covarrubias, s.v. tigeretas, resume el cuento que tan donosamente había contado el Arcipreste de Talavera), erre que erre, emperrarse, estar en sus trece. Las prédicas de Jesús no sólo andan descaminadas (echar por esos trigos, v. 394), sino que son machaconas. En cuanto a echarlo a doce (o echarlo todo a doce), dice el Dice. Aut. que es 'desbarrar, enfadarse y meter a bulla una cosa para que se confunda y no se hable más de ella'. Cf. Polo, Dafne: "... y por menos que esto lo eche a doce". Véase también infra, nota al v. 516.

422. El ms. dice respondiéronle.

426. Esto no lo puedo documentar sino con un cuento que oí en mi infancia: el héroe posee una tablita mágica, y cuando se ve en un aprieto le basta decir ;Tablita, compónte! para que todo salga a pedir de boca. 
sáquenos este vientre de mal año, que comiendo de valde a su despecho

430 quedará cada uno satisfecho.

Manos a la labor, vaya de presto, pues bien sabe el refrán Quien haze un cesto... '.

Pero aunque todo el pueblo lo pedía, a nada de esto el bruto se movía,

435 y después respondió, de importunado:

"No me hallo de milagros tan sobrado, pues sólo a mi pobreza los consagro; que tal estoy, que vivo de milagro".

"Estos prodigios - dizen- dirás luego

440 a quien le sirvan de oración de ciego, porque es un papasal y una quimera, y la ley de Moséh es la verdadera; que si al mundo fue dada por presente, mal puede ser passada.

445 Quien procura gozar eternas "glorias, lea la Ley, porque éssas son historias; $y$, según lo que tienes referido, aunque eres lerdo estás bien entendido*: castigando tu yerro

450 juro a Dios que han de darte pan de perro.

Diga, Dios, o basura, ¿no es del Señor eterno la Escritura?

Pues por su autor tal perfeción alcanza, que al son del tiempo no ha de hazer mudanza.

455 ¿Perfecta no la llama el sacro Apolo por no tener de más un punto solo? $\mathrm{Y}$ si es como el buen vino este conceto, ¿para qué ha de mudar lo que es perfeto?

Norte divino es la Ley constante,

460 que en la tormenta de este mundo errante hallamos con acierto en dos tablas de Ley seguro puerto. Sabe que por dar gloria y quitar pena

448. Entendido, no en la acepción de 'sabio' (antítesis de lerdo), sino en la de 'advertido', 'sobre aviso': si Jesús sigue así, lo que se va a ganar es una sentencia de muerte. El pan de perro (v. 450), según el Dice. Aut., es el 'pan con zarazas que se da a los perros para matarlos', y "metaphóricamente vale daño o castigo que se hace u da a alguno". Cf. también ibid., s.v. dar, la expresión dar pan de perro. 
Dios nos pegó su Ley, que fue una y buena,

465 y [a] unque* esta pieza fue de gran consuelo, no ha de pegarnos otra, ¡vive el cielo!

¿Por qué ha de creer cerrando entrambos ojos

ningún hombre tus bárbaros antojos?

Sólo en nuestros cuidados

470 dezimos la Semáh a ojos cerrados,

$\mathrm{y}$ aunque obres fingidas maravillas,

diremos la Hamida a pies juntillas*.

Si al Señor ofendió nuestra malicia,

que padezca Dios propio es injusticia.

475 Si la manzana le ofendió de veras, diesse Dios a los hombres para peras, y no, para perdón del hombre malo, quier[a] que le pongamos en un palo*.

Aquésta e[s] la verdad, y no al contrario;

y te dirá lo mesmo un boticario'".

Christo se vio enfadado,

y respondió irritado:

"Quando vengo a dar ley aun a los reyes, me dezís en la cara dos mil leyes.

485 ¡Qué linda mermelada!

Allá vendrá la Inquisición sagrada, y con ardiente furia

vengará de su Dios tan grande injuria'.

Ellos responden: "Essa calabaza

490 no es por vengarte a ti, que es de Dios traza

para castigo de su pueblo amado,

465. El ms. dice vnque, que no puede ser sino aunque. Pero debe de haber un error de copia. Ese aunque es ilógico: se espera más bien "y si esta..." (siendo la Ley vieja la buena, ¿por qué Jesús quiere "pegar" otra?).

472. En dos versos consecutivos de la "Alabanza jocosa a la Ley" menciona Barrios estos mismos rezos. SCHOLBERG, p. 343, notas 19 y 20, explica que la Semáh "es la oración céntrica de la religión hebrea" (en ella "se afirma la unidad de Dios") y que la Amidah (Hamida) "es una oración que siempre se dice de pie" (con lo cual se aclara el chiste de este v. 472, "a pies juntillas'). No explica Scholberg cómo se reza la Semáh, pero, a juzgar por el v. 470 de la Magdalena, se reza con los ojos cerrados.

478. En otras palabras, el dogma de la Redención es absurdo: si el hombre (Adán) ofendió a Dios, ¿por qué ha de morir Dios en la cruz? Lo lógico es que el castigo recaiga en el hombre. Dar para peras (v. 476) es 'cascar algún golpe o golpes a alguno, de género que le causen dolor sin derramar sangre' (o sea, 'dar un coscorrón'). 
como lo afirma aquel autor sagrado, pues por nuestros delitos a Dios plugo hazer la Inquisición, cruel verdugo*;

495 pues quien la Ley penetra verá al pie de la letra:

Tu buey verás, mi pueblo, degollado, y no comerás dél ningún bocado; te verás del temor tan perseguido,

500 que aun sin buscarte andarás huido*, adonde esgrime con fiereza estraña el castigo de Dios la dura España*. Mas esto es de manera que quando muere en la encendida hoguera

505 algún judío, sube en buelo sumo del fuego ardiente en la nariz el humo; y causando a Castilla los desmayos, contra sus humos vibrará sus rayos; siendo de Faraón exemplo inmundo,

510 morirán todos en el mar del mundo; castigando su error tan duro y ciego, padecerán en piélagos de fuego"*.

Él replicó: "Pues si en rigor tan fuerte pretendéis darme muerte

494. Los cristianos ven en la Inquisición el justo castigo de quienes "injuriaron" a Jesús (vv. 486-488); los judíos, en cambio, la ven como el instrumento escogido por Dios para purificar a su pueblo amado. Sobre esto véase infra, pp. 451-453.

500. Los dos primeros versos constan en efecto en la Ley (Deuteronomio, 28:31): "Tu buey será matado delante tus ojos, y tú no comerás de él". Los otros dos parecen proceder de un comentario rabínico que aplicaba ese texto a las calamidades sufridas por Israel en la Europa cristiana. El v. 500 es impresionante (seguramente hay que entender "aun sin que te busquen"). Durante largos siglos pensarían a veces los judíos europeos: "¡Vaya! Parece que nos han dejado en paz, pero ¿cuándo será el próximo pogrom?"

502. Otro verso impresionante. España ha tomado demasiado a pechos su papel de instrumento. En el Coro de las Musas, libro de la época en que Barrios nadaba entre dos aguas, hay un elogio ambiguo de Fernando el Católico, "Jovè nupcial de Palas eminente" (o sea: marido de la reina Isabel), que "fundó la Santa Inquisición, celante / campeón de la Fe"; tras lo cual el poeta dice que Fernando, deseoso de consolidar su Imperio, "echó más de ochocientos mil hebreos" fuera de su patria (ScholberG, p. 51).

512. El sujeto de vibrará (v. 508) es naturalmente Dios, el cual ahogará a los cristianos (como ahogó al Faraón y sus huestes) y los despachará como es debido al infierno. 
515 sin escuchar mi quexa, con mis onze de oveja* a la horca me iré como un cordero porque a ser mártir vengo, morir quiero, y el darla luego tengo yo por flores,

520 pues me escusan recetas de doctores.

Matadme luego al punto,

que me muero, ipor Dios!, por ser difunto;

pues a carga cerrada

tan largo viage no me cuesta nada".

525 "¿De balde? - replicaron- No lo creas:

del cuero han de salirte las correas*;

primero han de venderte'". Y luego fueron

y por treinta dineros lo vendieron.

¡Treinta dineros! ¡Oh, qué vil desprecio

530 vender a un Dios barbado por tal precio!

¿Qué miserable engaño!

¿No dieran treinta y tres, uno por año?

Ahorcado tal barato,

quando hoy por más se vende su retrato,

535 llegando su miseria a tal estado, que fue el original peor que el traslado, pues con perversos tratos siempre anduvo de Herodes a Pilatos.

Después le sentenciaron,

540 y [a] ahorcar los judíos le sacaron.

Subió por la de palo

como si a comer fuera algún regalo, donde tuvo la paga merecida.

Su muerte estuvo en la fatal subida.

545 Muriendo desta suerte

vino a ser Christo un Dios de mala muerte;

516. La expresión con sus once de oveja se usa "para dar a entender que alguno se entromete en lo que no le toca". Cf., en Polo de Medina, estas palabras de Dafne a Apolo: “¿No hay sino, perdiéndome el decoro [...], / venir estirándose de ceja, / con sus once de amor, como de oveja?" En La Verdad, vv. 611 614, Barrios pone en boca del Apetito estos versos: "Yo entonces iré al balido / si con mis once de oveja / la veo [a la Ley] echar todo a doce / para meterme en docena" (alusión, según parece, a las doce tribus de Israel). Sobre echarlo todo a doce véase antes, nota al v. 399.

526. Otro chiste boomerang, en vista de la proverbial avidez de dinero de los judíos. 
y si antes fue un cuitado, después se vido el Dios más estirado*; y si nació causando admiraciones

550 entre bestias, murió entre dos ladrones (pero la autoridad fue su remedio, gozando, por mayor, su puesto en medio), y en la cruz con cuidado de pies y manos se miró clavado.

555 La sutileza del judío alabo, que supo a un Dios pegársela de clavo*.

A este tiempo llegó la Magdalena respa[h]ilando* en planta de su pena; $\mathrm{y}$, viéndole en la cruz ya sin aliento,

560 cabiztuerto y el rostro macilento, llorando con enojos hizo barreños de fregar los ojos, y por lavar sus pies ya sin trabajo, sirvieron sus cabellos de estropajo.

565 Con esto* su funesta historia acabe; y si subió a los cielos Dios lo sabe, que otros dizen que, por más trabajos, Jesús passó a los Países Baxos a librar de tormentos temerarios

570 a no sé quántos padres trinitarios*. Esto creeré yo para in eterno; y si él baxó, quedóse en el Infierno.

Éste es el cuento, y si del punto salgo, bien puedo a una mentira añadir algo,

548. Magnífico chiste, de obvio significado, y no distinto de los que se hacían del lado cristiano, por ejemplo a propósito de San Lorenzo y la parrilla. Pero eso de que Jesús comenzó su carrera como pobre diablo y acabó muy estirado no creo que un poeta cristiano se atreviera a escribirlo.

556. Cf. pegársela a alguien 'darle chasco', y arrimarle el clavo 'engañarle' (Covarrubias); también echar clavo o meter de clavo 'engañar' (Dicc. 'Aut.).

558. Restituyo la $h$, que falta en el ms., para que consten bien las once sílabas del verso. Según el DRAE, respailando (o raspailando) significa 'moviéndose rápida y atropelladamente'. COROMINAS cita un raspahilando de Cervantes, un raspailando de Quiñones de Benavente y un respailando de Quevedo.

565. El ms. dice $Y$ con esto.

570. El adjetivo temerarios es a todas luces un ripio para meter a los trinitarios. ¿Se referirá Barrios a una intervención de estos frailes en "los Países Baxos", o sea en Bruselas o en Amberes? ¿O esos Países Bajos serán simplemente el infierno, y los trinitarios los que creen en la Trinidad? 
575 porque dexar que todo se lo mienta el Ovidio Evangelio, es afrenta, y el que a bóbilis bóbilis lo creere haga lo que quisiere, que en Josaphá con fuerte carretilla

580 le leerán a cada uno su cartilla.

Escrito por su autor, si no me engaño, a tantos deste mes y deste año*.

\section{Finis}

La Fábula de Cristo y la Magdalena no está muy bien hecha. Barrios, que escribió muchos centenares de páginas de versos, tiene algunos poemas bien acabados, pero en general no es muy cuidadoso: escribe de prisa, sin quebrarse mucho la cabeza. No es un artista de la talla de Polo de Medina o de Sor Juana. No hay en la Magdalena la gracia sostenida, el chispeante fluir de ocurrencias, la atención al conjunto que brillan en la Fábula de Apolo y Dafne y en el Retrato de Lisarda. He señalado, por ejemplo (supra, p. 412) cómo Polo y Sor Juana se las arreglaron para no caer en el peligro del ripio, especialmente insidioso en las silvas de pareados. No así Barrios" ${ }^{52}$. Está bien el chiste "María blanca y Joseph cornado" (v. 78), pero el verso anterior, "según tengo imaginado", es un relleno, un ripio que salta a la vista. Está bien decir que Jesús fue tal vez un "hijo sin padre" (v. 82), pero el "porque assí te quadre" es un ripio desvergonzado. $\mathrm{Y}$ baste con esos ejemplos. (Ya he mencionado supra, p. 426, los defectos de métrica.)

Bien visto, el título no es muy adecuado. Más de dos terceras partes de la composición están ocupadas por materias que pedirían más bien un título como Sátira o Diatriba contra Cristo y el cristianismo; el cuento de los "amores" de Cristo y la Magdalena viene a ser un simple episodio; ocupa sólo 182 versos (143-316 y 557-564), y 114 de esos 182 no son de narración ni descripción, sino de diálogo (eso sí, sembrado de agudezas, sobre todo la ré-

582. Cfi el colofón de Sor Juana a su Retrato de Lisarda: "Veinte años de cumplir en mayo acaba. / Juana Inés de la Cruz la retrataba".

${ }^{52}$ En $L a$ Verdad, la silva de pareados le sirve a Barrios para parlamentos largos, puestos en boca de personajes serios: la Verdad (jornada I), el Albedrío (II) y el Celo (III). 
plica de la Magdalena, 245 ss, , tan quevedesca). Pero añadir a la serie de fábulas burlescas de Apolo y Dafne, de Pan y Siringa, de Diana y Acteón, etc., una de Cristo y la Magdalena no dejaba de ser "picante". Es, pues, un título "sensacionalista" (y que a mí me sedujo).

Se tiene la impresión de que la Magdalena iba a comenzar en el actual v. 29: "Estando, como poeta pensativo [. . . ], / de súpito me vino al pensamiento / contar...', y que Barrios añadió después los 28 versos del actual comienzo -donde por cierto repite que se trata de un impromptu ("sin más ni más me vino a la memoria" $)^{53}$-, sin preocuparse para nada del engarce. Donde más se nota la falta de un engarce es entre los vv. 86 y 87 . En el 86 terminan unos comentarios sobre el nacimiento de Jesús, hijo de María pero no de José (sino tal vez de un herrero); y en seguida viene un salto: "Con ocioso descanso y grande espacio / Jesús pisava el celestial palacio..." . También esta parte tiene que haber sido un injerto posterior, un afterthought. Y la explicación es fácil. Hay unas quintillas "joco-serias" de Jerónimo Cáncer "Al Nacimiento", que comienzan así:

Pues nadie me lo estorbó, contaros agora intento sin que falte un sí ni un no, del modo que Dios nació, que fue muy estraño cuento.

Viendo el Padre divinal, en quien todo el bien se encierra, que su Hijo natural, por redemir nuestro mal baxar quería a la tierra,

dixo (con saber profundo que es bien que a todos asombre) que, aunque no es hijo segundo, vaya y ruede por el mundo, que assí vendrá a hazerse hombre...

Es claro que la metáfora de Cáncer - un padre muy rico que le dice a su hijo (a pesar de no ser segundón) que ya es hora de ir a rodar por el mundo y hacerse hombre - le gustó a Barrios ${ }^{54}$, el

53 Otra repetición muy torpe: "el pintar sus matizes es mui justo", dice en el v. 147; y poco después, en el 166: "el pintar sus matizes viene a pelo".

${ }^{54}$ En el ms. madrileño, la Magdalena termina al final del folio $11 \mathrm{r}^{\circ}$, y en 
cual se esmeró en orquestarla y ponerla en fortissimo. En primer lugar, añade por su cuenta una bonita descripción del palacio celestial, inmenso y cuajado de resplandecientes estrellas, y en segundo lugar extrae de la situación buenos jugos satíricos: ese muchacho comodón, bueno para nada, no "quiere bajar" a la tierra, como en Cáncer: aquí es el Padre quien con frases terminantes ("No ha de ocuparme más estos balcones", "Aquí no ha de quedarme hasta mañana") y con leccioncitas de viejo experimentado ("Entre los suyos nadie medra", "El cielo es tierra donde no se gana") expulsa de la etérea casa al remolón muchacho: ¿Ea, basta de holgazanear! Salga usted de aquí cuanto antes y échese al mundo a hacer su lucha', etc. (y hay que reconocer que no le falta sal $)^{55}$.

Lo "sustancial" del poema no está en los 182 versos dedicados a Cristo y la Magdalena, sino en el resto, sobre todo en los 193 versos (335-527) del diálogo de Cristo con 'los judíos", donde hay una exposición de la Ley de Moisés (442 ss.) que podría estar muy cómodamente en la comedia de La Verdad, salvo que en ésta la voz de Cristo - y del cristianismo- sale de boca del Error, el Vicio y la Mentira.

Por otra parte, en la porción sustancial hay, como no podía ser menos, dada la formación cristiana de esta "alma en litigio", muchas reminiscencias cristianas y, concretamente, irreverencias "blandas" que bien pudieron haber salido de plumas como la de Cáncer o la de Ledesma. En varios pasajes podría un lector católico aplaudir sus hallazgos, corno cuando dice que Jesús no poseía riquezas "por ser tan pobre que nació en las pajas" (v. 268). El último discurso de Cristo (513 ss.) es perfectamente "cristiano". Barrios, desde luego, sabe cuanto podía saber — por el oídocualquiera que se hubiera criado en una ciudad como Montilla hasta los 17 o 18 años: que Cristo fue concebido virginalmente en

seguida hay, de mano distinta, una copia de las quintillas de Cáncer, con un primer verso métricamente monstruoso: "Ya que el tiempo me lo consintió, / contaros ahora intento...". Esa alteración del primer verso parece haberse hecho para relacionar las quintillas con la alusión al Tiempo que hay al comienzo de la Magdalena (vv. 8 y 13); como si dijera: 'Ya que la rueda del Tiempo me lo permite, quiero que vean ustedes cómo cuenta Gáncer el episodio que yo cuento en los vv. 87 ss. de mi Fábula'. - Cáncer termina su cuento con la adoración de los Magos: al verse “con tres Reyes”, Jesús gritó: “ „Esta vez yo soy hombre!" ('con tres cartas tan buenas ya gané el juego'). El mismo chiste está en la Magdalena, v. 136: "con tres Reyes se vio puesto a primera".

${ }_{55}$ Resultado de este injerto es que también se cuenta dos veces (vv. 60-64 y 122-126) cómo "se entró" Cristo en el vientre de María. 
el vientre de María (72, 284) sin intervención del paciente (65 ss.) y humilde carpintero San José (53); que nació en un pesebre (127, 268) entre una mula y un buey (550) y fue adorado por los Magos, uno de los cuales era negro (133-138); sabe que Cristo hizo muchos milagros (409 ss.), que predicó (317 ss.), que proclamó una ley nueva, llamada Ley de Gracia (340 ss., 390); que sús doce discípulos dejaron todo por seguirlo (34-36); que María Magdalena le tuvo mucho amor (143 ss., 557 ss.); que entró en Jerusalén montado en un asno, según la profecía (337); que padeció mortales sudores en el huerto de Getsemaní (294); que, manso "cordero de Dios" (331, 517), fue vendido por treinta dineros (528), llevado "de Herodes a Pilatos" (538) y azotado y crucificado por los judíos $(295,329,540,556)$ entre dos ladrones $(550)$; que resucitó (326), descendió a "los infiernos" (572) y ascendió luego a los cielos (566). Están presentes en la Magdalena los dogmas de la Trinidad (327), del Pecado Original $(321,475)$ y de la Eucaristía (386), pero muy particularmente el de la Encarnación (64, 126, 325) y el de la Redención: Cristo fue el Mesías (320) enviado por el Padre Eterno (96 ss., 285) para redimir y salvar al género humano $(364,401,477,518)$.

Como para curarse en salud, una y otra vez necesita Barrios hacer constar que todo eso es mentira, tan mentira como las historias que se cuentan de os dioses del paganismo, y para ello acude una y otra vez a la retórica de la ironía. El nacimiento de Cristo - dice- pudo perfectamente haber sido algo extraordinario: $i^{\mathrm{a}-}$ caso no hay autores de mucho prestigio que dicen que Venus nació de la espuma? (84); Jesús no es un dios cualquiera: es tan respetable como "el mismo Júpiter" (20), y el cristianismo tan verídico "como el Evangelio" (40); Cristo merece tanta atención como los demás dioses, pues " ¿son acaso los otros más mentira?" (24); y, en fin, a un poeta moderno se le permitirá añadir dos o tres méntirillas a la mentira establecida: no hay razón para dejarle la exclusiva al "Ovidio Evangelio" (573 ss.) $)^{56}$.

Merece examen atento el pasaje sobre la Inquisición (486512), porque allí expresa Barrios, y con mucha eficacia, los sentimientos de muchos judíos españoles. Según los comentarios rabínicos - supongo que desde la Edad Media-, las calamidades sufridas por Israel, y concretamente las hogueras de la Inquisi-

${ }^{56} \mathrm{El}$ argumento del v. $34-i$ Miren qué sólidos testigos de la verdad del cristianismo: "doze pescadores"! - no es muy acertado: el Dios bíblico era muy aficionado a valerse de seres humildes para dar testimonio de Sí mismo. 
ción, eran "castigo por la idolatría cometida en tiempos de Nabucodonosor"' (!). En esos comentarios se había inspirado Pinto Delgado cuando, dirigiéndose a "Jerusalem' en lenguaje imitado de Jeremías, decía: "Oh ciudad [...], / ¿quién a mirarte se inclina / y a tus muros derrocados / por la justicia divina, / que no vea en tus pecados / la causa de tu ruina?" (OELman, pp. 189191). En La Verdad (vv. 2738-2757) mete Barrios dos décimas que llaman la atención por estar insertas, las dos solas, entre pasaje y pasaje de romance. En la primera décima dice la Mentira (el cristianismo) que Israel no debe de estar bien con Dios, puesto que Dios lo castiga tan horriblemente; en la segunda replica el Celo (el judaísmo): "Dejarle en el desconsuelo / es justicia, no rigor, / pues castiga así su error / por premiar después su celo". Y en la Magdalena, cuando Jesús da la versión cristiana - la Inquisición es "venganza"' de Dios contra el pueblo deicida-, los judíos le replican exponiendo detenidamente su propia versión: las hogueras, los horrores, son "traza" de Dios "para castigo de su pueblo amado", castigo del cual le plugo nombrar ejecutora a la dura España, como dice el admirable verso 502.

La Inquisición está presente en los tres poetas marranos estudiados por Oelman ${ }^{57}$, pero muy particularmente en Barrios. En la "Alabanza jocosa a la Ley", el Santo Oficio es la bestia de diez cuernos (de que habla el profeta Daniel, cap. 7), "con cuernos siete en Esperia/y con tres en Lusitania" ${ }^{58}$. La muerte de aquel joven primo, Marcos de Almeida, quemado en 1655, debe de haber pesado mucho en el recuerdo de Barrios, y seguramente fue esto lo que lo movió a convertirse en cronista y panegirista de los judíos españoles caídos en garras de la bestia. En el Triumpho del govierno popular incluyó una detallada "Memoria de los mártires que fueron quemados vivos en diferentes tiempos y ciudades de España' (Scholberg, p. 343, nota 26), y escribió poesías en

57 "La afirmación más completa y abierta del sentimiento judaico" de Enríquez Gómez - que fue "el menos abiertamente judío de los tres" - es el Romance al divín mártir, inspirado en un hecho insólito: el martirio de cierto Lope de Vega y Alarcón, español "de familia de cristianos viejos" que se convirtió al judaísmo y fue quemado en Valladolid en 1644 (OELman, pp, 194197). Es raro que no mencione Oelman el "pamphlet contre l'Inquisition" de Enríquez Gómez que publicó I. S. RÉvaH en REJ, 121 (1962), 81-169.

${ }^{58}$ ScholberG, p. 344, nota 27, identifica los tres cuernos de Lusitania (Lisboa, Évora y Coimbra), pero dice que en Esperia, o sea en España, no fueron siete sino trece los cuernos "en el período de más actividad" ( $y$ los enumera). A ellos hay que añadir los del Nuevo Mundo, documentados y estudiados por José Toribio Medina. Véase la nota siguiente. 
loor de ellos, de las cuales Scholberg, pp. 240-245, reproduce seis sonetos y dos composiciones en décimas ${ }^{59}$. Finalmente, en la supercalderoniana comedia de La Verdad (véase el título completo supra, p. 416), que en medio de una tremenda balumba de alegorías tiene de pronto pasajes buenos ${ }^{60}$, la palabra mártir asume su significado etimológico de 'testigo': “Lo que en los autos sacramentales es la apoteosis de la Eucaristía, es [en La Verdad] la glorificación del Kidush ha-shem, la 'santificación del Nombre' por el martirio" (ScHOLBERG, p. 119). El sobreabundante vapor alegórico se condensa en la exaltación de "los tres bienaventurados mártires" de Córdoba, "todos tres en España confesando / sólo al Dios de Israel, atropellando / a los de palo y piedra" 61.

Estos "dioses" de palo y piedra nos llevan al tema de la idolatría, una de las abominaciones más insistentemente repudiadas en la Biblia. 'No nos venga a nosotros con prédicas', le dicen los

${ }^{59}$ Uno de los sonetos está dirigido "A la gloriosa constancia del bienaventurado mártir Tomás Tremiño de Sobremonte (alias Ishac Israel), natural de Rioseco, que después de catorce años de dura prisión padeció martirio de fuego en la ciudad de México". Según Joaquín García ICazBalceta, "Noticia de los autos de fe celebrados en México" (desde los inicios hasta 1803), en su Bibliografía mexicana del siglo xvi, ed. Agustín Millares Carlo, México, 1954, p. $456 b$, el único quemado vivo de los 108 reos penitenciados en el grandioso auto de 11 de abril de 1649 (cuando Barrios tenía 14 años) fue "el famoso judío Tomás Treviño de Sobremonte". Millares Cario remite a J. T. Medina, Historia del tribunal del Santo Oficio de la Inquisición en México, cap. 13, que trata detalladamente de ese auto de fe. Desde fines del siglo Xvi hasta fines del xvII la mayor parte de los reos mexicanos son judaizantes. El último caso que registra Icazbalceta es de 1702.

${ }^{60}$ Me llama la atención la variedad métrica de esta comedia: cuento hasta 45 saltos de un metro a otro. (El análisis métrico de ScHOLBERG, pp. 111-118, es minucioso pero no muy exacto.)

${ }^{61}$ En el ms. Ets Haim, la Magdalena está junto a una "Relación de la Inquisición y de lo que padeció en ella Antonio de Fonseca"; véase supra, p. 425, nota 49. En la bibliografía de Barrios incluye ScholBERG, p. 353, lo siguiente: "Trompeta del Juizio contra el Papa y la Inquisición, Sátyra (sin nombre, lugar ni año). Br[itish] M[useum], 4033.a.37. Atribuido a Barrios". Por desgracia, no dice más. No figura en PalaU, y sospecho que se trata de un manuscrito. La atribución parece muy razonable: esa Trompeta está en Londres porque aquí vivían los destinatarios de algunos de los escritos de Barrios; así varias epístolas, como la dirigida "Al muy ínclito gobierno del Kahal Kadós de Londres" (Scholberg, pp. 230-232; y cf. su nota 92); así también el Atlas angélico de la Gran Bretaña, dedicado a Jacobo II (ID., p. 40), y la Historia real de la Gran Bretaña, dedicada a Guillermo III (ID., p. 79). Hay que añadir que el manuscrito madrileño de la Magdalena fue propiedad de Pascual de Gayangos, el cual ciertamente no lo acquirió en España, sino en Londres. 
judíos a Cristo en la Magdalena; que mejor vaya y "predique a los cristianos / que no adoren las obras de sus manos"' (v. 384), que no acudan a "dioses hechos de manos de hombres, a madera y a piedra, que no ven ni oyen ni comen ni huelen'" (Deuteronomio, 4:28) ${ }^{62}$. La postura de Barrios es aquí ortodoxamente judaica. Bien que le constaba lo que era en España y en Italia el culto de las imágenes. No sólo eso: él mismo se había arrodillado ante ellas: "Confieso que idolatré...", dice en un acceso de compunción (supra, p. 419). Pero ¿llegaría verdaderamente a aborrecer las imágenes cristianas? Creo que la respuesta a esta pregunta está en los vv. 139-142 de la Magdalena. Ya el escamoteo del "retrato" del héroe (obligatorio en toda fábula burlesca, y forzosamente caricaturesco, o en todo caso humorístico) es muy revelador. Barrios sale del paso con una buena razón -y excelente chiste-: a Cristo él 'no lo puede ver ni en pintura'. ¿Por qué añade entonces que 'además, abundan las representaciones artísticas de la hermosura de Cristo'? No es arriesgado suponer que, así como se enamoró de los versos de los españoles cristianos, así también se enamoró de tantas pinturas y esculturas religiosas (y también profanas) ${ }^{63}$ que vio en España y en Italia. Barrios tenía ante los ojos del alma el retrato de Cristo a causa de "tanto pinzel de su hermosura" como había admirado en sus mocedades ${ }^{64}$. Le era imposible convertirlo en adefesio.

${ }^{62}$ Idea desarrollada en dos Salmos (115:4-8, 135:15-18) y hermosamente expuesta en Isaías, 44:9-19, el cual presenta en acción a un fabricante de ídolos, al mismo tiempo que hace persuasivos razonamientos para que Israel no adore esas cosas. Es claro que tales razonamientos eran necesarios. Los judíos caían y recaían constantemente en la idolatría, como a todos es notorio.

${ }^{63}$ Podemos imaginar a Barrios en conversación con el dibujante Dipenbeke cuando éste preparaba las preciosas ilustraciones mitológicas de la Flor de Apolo.

${ }^{64}$ Bien sabía el Profeta que los ídolos son seductores: en cierto momento dice cómo el artífice talla el bloque de madera "en forma de varón, a semejanza de hombre hermoso" (Isaías, 44:13). Viene muy a propósito algo que cuenta Barrios en su Triumpho del govierno popular: Lorenzo Escudero, alias Abraham Israel, vivía "en gran miseria" en Amsterdam; un día se entrevistó en Bruselas con el gobernador de Flandes, marqués de Caracena; éste se mostró dispuesto a ayudarlo y le hizo "grandes promesas" a condición, claro, de que abandonara la Ley mosaica; Escudero decía que eso de ningún modo; y entonces - medida suprema - el marqués lo llevó a cierta iglesia "por ver si se reducía mirando a las imágenes". ¡Pero nada! El héroe "quedó tan entero en su firmeza, que se cubrió delante de ellas con el sombrero que antes no tenía puesto" por respeto al marqués (Scholberg, p. 72). La historieta está contada en el más puro estilo hagiográfico. Cuando el que escribe la vida de un 
Y hasta podemos asegurar que sabía perfectamente que una buena representación de la hermosura de Cristo no era barata (cf. el v. 534).

También abundaban los "pinceles" de la hermosura de la Magdalena, y es notable cómo, al retratarla a ella (145 ss.), varias veces olvida Barrios las leyes del género burlesco, por ejemplo cuando dibuja las cejas: "dos líneas de azabache son, tan bellas...', y lo que sigue, versos que nadie calificaría de burlescos. De nuevo, sus verdaderos amores le impidieron hacer una buena caricatura. Hubiera podido convertir a la Magdalena en una Maritornes, semejante a la Hero del romancillo de Quevedo, "corita en cogote / y gallega en ancas [...], / las uñas con cejas / de rascar la caspa". Pero no: su Magdalena es sin duda una mujer hermosa, y Jesús tuvo en efecto "lindo gusto"' (v. 148) al requerirla de amores.

El cristianismo pesaba fuertemente en Barrios. Y también su fundador, Cristo. Al decir Barrios que "le es aficionado" (v. 25) está haciendo, todo lo malgré lui que se quiera, una confesión sincera. Además, Cristo "es su pariente”' (v. 80): ¡Gristo es judío! La señal más pasmosa de su cristianismo es que no sólo les da la razón a los cristianos "sabios" (12) que dicen que los judios crucificaron a Cristo (él lo admite, y en tres lugares: vv. 295, 540 y 556), sino también a los cristianos del vulgo que dicen que los judios lo azotaron (330), cuando es claro que esto lo hicieron los soldados romanos, y que los judios "lo vendieron" por treinta dineros (528), cuando es claro que lo que hicieron los judíos fue comprárselo a Judas.

Algo que delata "la influencia imborrable del ambiente cristiano", en Barrios lo mismo que en Enríquez Gómez y hasta en Pinto Delgado, es "la aceptación de una doctrina como la del Pecado Original, aun en un nivel metafísico" (Oelman, p. 187). En la Magdalena esta aceptación es inequívoca (321 y 473-475). Y la doctrina está presente, textualmente o entre líneas, en $L a$ Verdad, en los Días penitenciales y en una serie de composiciones sobre la Ley, que Scholberg (p. 41) cuenta entre "sus poemas

santo cuenta una de sus hazañas de virtud, dice siempre, explícita o implícitamente: 'Nosotros, cristianos del montón, ¿seríamos capaces de tamaño heroísmo?'; Barrios insinúa que él no hubiera tenido la heroica resistencia de Escudero. - Escolio: He leído u oído hablar de protestantes que abrazan el catolicismo seducidos por el esplendor visual de los templos católicos. (En los templos protestantes podrá haber una que otra imagen. En las sinagogas, nada. ¿Qué desnudas le parecerían a Barrios!) 
más logrados" 65, por ejemplo la "Eternidad de la Ley de Mosséh", la ya mencionada "Alabanza jocosa a la Ley santísima" y "La mayor perfección, la Ley santísima", donde se lee que la Ley es en efecto la perfección misma, "mas el hombre por el cuerpo / se muda y corrompe, desde / que por serpentino engaño / quedó sujeto a la muerte" (ScholberG, p. 129)66.

De hecho, el núcleo de la Magdalena, su tema central, es la excelsitud de la Ley de Moisés y la inanidad de la ley de Cristo. $Y$ es muy natural que los elementos burlescos se adelgacen y desvanezcan en estos pasajes, bastante largos (339 ss., 442-446, 452466). El tono que aquí domina es el doctrinal, parecido al de muchos largos pasajes de La Verdad. Pero también aquí cabe señalar un rasgo cristiano de Barrios: será descuido, será muestra de imparcialidad, pero el hecho es que en el v. 344 recoge sin chistar la solemne declaración de Cristo (Mateo, 5:17): "No penséis que he venido a abrogar la Ley o los Profetas".

Así como muchos pasajes de la Ley y los Profetas insisten en la prohibición de la idolatría, así muchos insisten en la prohibición de comer la carne de animales "inmundos", ilustremente representados por el cerdo. Puede decirse que la abstención de carne de cerdo fue, para los españoles de los siglos xVI y xvII, el rasgo más llamativo y caracterizador del judíi ${ }^{67}$. Sabido es cómo muchos criptojudíos fueron descubiertos a causa de sus

${ }^{65}$ Scholberg, pp. 121-123 y 129-137, publica varias de estas composiciones exaltadoras de la Ley, y dice (p. 41) que uno de los últimos escritos de Barrios fue el intitulado Monte hermoso de la Ley divina (1699).

${ }^{66}$ En cambio, no hay en la Magdalena ninguna alusión a la doctrina del libre albedrío. Pero el Albedrío es uno de los personajes principales de $L a$ Verdad. Y Libre albedrio se llama un largo y curioso romance (ScHOLBERG, pp. 90-92 y 139-156) en que Barrios polemiza con los judíos que niegan esa doctrina, y comienza citando como autoridades a Orígenes y a Santo Tomás de Aquino (!). - A propósito de un marrano de la generación anterior, Abraham Pereyra, que plagia a fray Luis de Granada, a fray Diego de Estella y al Quevedo de La cuna y la sepultura (evitando, eso sí, cualquier alusión al Nuevo Testamento o a los Santos Padres), y que "cree en el pecado original, cree en el diablo [...], en el libre albedrío, en la gracia divina" y muestra "las mismas preocupaciones que las de los escritores peninsulares", J. A. VAN PRAAG, art. cit., hace este comentario: "¿Y por qué no? La moral del catolicismo es en su fondo la moral del judaísmo". Añádase que Barrios tenía "firme creencia en una vida perdurable después de la muerte" (Scholberg, p. 75).

${ }^{67}$ Gf: Quevedo: "Yo te untaré mis versos con tocino / por que no me los muerdas, Gongorilla..."; tal vez apunta también a Góngora el soneto "Adoro aunque te pese...", que termina: "... no le persigas en el pan 
costumbres alimenticias "raras". Por otra parte, es un hecho que, desde los tiempos arcaicos hasta los modernos, hubo siempre judíos que comieron carnes prohibidas ${ }^{68}$. Si los autores de la Biblia remacharon tanto la prohibición, fue porque había transgresores; y si la conducta de los Macabeos se destaca como algo extraordinariamente ejemplar y heroico (II Macabeos, caps. 6 y 7), es porque sus contemporáneos judíos no fueron capaces de tamaña constancia.

La manera como este tema aparece en la Magdalena es muy reveladora de la actitud de Barrios. Cuando Jesús trata de ganarse a los judíos, su mejor argumento es decirles (347 ss.): 'En mi religión es lícito el tocino ${ }^{69}$ : abandonad la Ley de Moisés porque éssa os lo quita'. Pero si “os lo quita”, es porque antes lo teníais. Eso es, en efecto, lo que pasaba con muchos judíos, entre ellos el propio Barrios: a él le quitaron el tocino (tal como le quitaron el culto de las imágenes y trataron de quitarle sus entrañables aficiones literarias). Si Barrios pasaba por cristiano en Bruselas, sería, entre otras cosas, porque no le hacía ascos al tocino. Hay en La Verdad una escena muy significativa: el Apetito, autorretrato alegórico del poeta como mal judío, dialoga con la Verdad, que trata de convertirlo en buen judío. El parlamento más largo de esta escena (vv. 1400-1418) es del Apetito: dice que a él nadie le va a quitar las cosas que le gustan, y lo primero que declara es: " "más la cebolla / estimo que su maná" (el maná de Dios). Es el locus classicus de la "carnalidad" de los judíos: ¡les llueve el maná, pan del cielo, y ellos lloran acordándose de las cebollas de Egipto! (Números, 11:5). Naturalmente, una de las cosas que le gustan al Apetito es ésta: "de las carnes, la que engorda"... (Al final de la comedia abandona el Apetito sus gustos y abraza plenamente la Ley: "Quiero buscar de Mosseh / los libros, porque imagino / que el que no se llega a ellos / no sabe cuántos son cinco"; a ese arrepentimiento corresponden los poemas "peniten-

siquiera; // pues en tu boca, a lo que yo imagino, / no le tomaras nunca si Él hubiera / no quedádose en pan, sino en tocino" (ed. Blecua).

${ }^{68} \mathrm{He}$ aquí, como ilustración, un chiste judío moderno (creo que de los coleccionados por Freud, pero no me consta). En una tienda de Delikatessen, un judío pide medio kilo "de ese salmón". "No es salmón, sino jamón”, explica el tendero; y el judío: "Déme medio kilo de ese salmón que parece jamón".

${ }^{69}$ Jesús nunca dijo tal cosa. Quien hizo lícita la carne de cerdo fue San Pablo (para gran consternación de San Pedro). Pero aquí, como en otros lugares de la Magdalena, Cristo significa 'el cristianismo'. 
ciales" de Barrios: supra, pp. 418-420. Pero bien podemos imaginar que él nunca dejó de suspirar por "las cebollas de Egipto".)

Después de decir que, de las carnes, la que prefiere es "la que engorda", el Apetito añade, sorprendentemente: "de los pescados, la hostia; / de los milagros, el vino". Es claro que el vino, jamás prohibido a los judíos ${ }^{70}$, no está aquí sino para acompañar a la hostia, que es 'ostia' (ostión, ostra) y a la vez 'la Hostia'. También en la Magdalena (386-388) están presentes la hostia y el vino, acompañados de un comentario anodino: iqué clase de Dios es ese a quien los cristianos se comen "a bocados" en la hostia, y cuya sangre beben en el vino "consagrado"! De la misma manera que no pudo convertir a la Magdalena en una pelandusca, tampoco pudo Barrios vilificar a fondo la Eucaristía, como denodadamente hizo el morisco anónimo que dijo: ¡qué clase de Dios es ese que entra por la boca, pasa a la barriga, sale "por aquel postigo viejo" y acaba en la letrina!71. El curioso "Enigma" de Quevedo que comienza "Si a compasión os provoca...", con su insistente machacar en la idea de comer a Dios y beber su sangre, es más jugoso y "picante" que lo que leemos en la Magdalena. Una vez más se nos muestra Barrios como "alma en litigio". Ese Barrios que comió carnes prohibidas y que veneró las imágenes cristianas, ¿no habrá experimentado algún consuelo espiritual al recibir la Comunión? ¿ No será ese recuerdo lo que le impidió llegar más lejos?

Antonio Alatorre

El Colegio de México

${ }^{70}$ Cuando dice el Apetito que el vino es el mejor "de los milagros", podría entenderse que es el invento humano más maravilloso de todos; pero seguramente quiere decir que de los milagros de Cristo, el más sensacional fue el que hizo en las bodas de Caná.

${ }^{71}$ Romance publicado por L. y D. Cardaillac y citado parcialmente por Luce López Baralt en BHi, 82 (1980), p. 41. 